bioRxiv preprint doi: https://doi.org/10.1101/2020.07.30.227561; this version posted July 30, 2020. The copyright holder for this preprint (which was not certified by peer review) is the author/funder, who has granted bioRxiv a license to display the preprint in perpetuity. It is made

\title{
Riluzole suppresses growth and enhances response to endocrine therapy in ER+ breast cancer
}

${ }^{1}$ Hillary Stires, ${ }^{1}$ Ayodeji O. Olukoya, ${ }^{2}$ Shihong Ma, ${ }^{1}$ Sonali Persaud, ${ }^{1}$ Yanira Guerra, ${ }^{1} \mathrm{M}$. Idalia Cruz, ${ }^{1}$ Carlos Benitez, ${ }^{1}$ Aaron Rozeboom, ${ }^{1}$ Hannah Ceuleers, ${ }^{1}$ Deborah L. Berry, ${ }^{3}$ Britta M. Jacobsen, ${ }^{2}$ Ganesh V. Raj, and

${ }^{* 1}$ Rebecca B. Riggins

${ }^{1}$ Department of Oncology, Lombardi Comprehensive Cancer Center, Georgetown University, Washington, DC. ${ }^{2}$ Departments of Urology and Pharmacology, University of Texas Southwestern Medical Center at Dallas, Dallas, TX

${ }^{3}$ Department of Pathology, University of Colorado Anschutz Medical Campus, Denver, CO

*To whom correspondence should be addressed: rbr7@georgetown.edu 
bioRxiv preprint doi: https://doi.org/10.1101/2020.07.30.227561; this version posted July 30, 2020. The copyright holder for this preprint (which

was not certified by peer review) is the author/funder, who has granted bioRxiv a license to display the preprint in perpetuity. It is made available under aCC-BY 4.0 International license.

Abstract

Background. Resistance to endocrine therapy in estrogen receptor-positive $(E R+)$ breast cancer remains a significant clinical problem. Riluzole is FDA-approved for the treatment of amyotrophic lateral sclerosis. A benzothiazole-based glutamate release inhibitor with several context-dependent mechanism(s) of action, Riluzole has shown anti-tumor activity in multiple malignancies, including melanoma, glioblastoma, and breast cancer. In several (but not all) of these studies, Riluzole-mediated growth inhibition is attributed to increased expression of metabotropic glutamate receptors (mGluRs, GRMs). We recently reported that acquisition of Tamoxifen resistance in a cellular model of invasive lobular breast cancer is accompanied by the upregulation of GRM mRNA expression and growth inhibition by Riluzole.

Methods. In the current study, we tested the ability of Riluzole to reduce cell growth, alone and in combination with endocrine therapy, in a diverse set of ER+ invasive ductal and lobular breast cancer-derived cell lines, primary breast tumor explant cultures, and the estrogen-independent, ESR1-mutated invasive lobular breast cancer patient-derived xenograft model $\mathrm{HCl}-013 \mathrm{El}$.

Results. Single-agent Riluzole suppressed the growth of ER+ invasive ductal and lobular breast cancer cell lines in vitro, inducing a histologic subtype-associated cell cycle arrest (G0-G1 for ductal, G2-M for lobular). In an invasive lobular, endocrine resistant model, Riluzole induced apoptosis and reduced phosphorylation of multiple pro-survival signaling molecules, including Akt/mTOR, CREB, and Src/Fak family kinases. Riluzole in combination with either Fulvestrant or 4-hydroxytamoxifen additively or synergistically suppressed ER+ breast cancer cell growth in vitro. The combination of Riluzole plus Fulvestrant significantly reduced proliferation in primary breast tumor explant cultures, and inhibited $\mathrm{HCl}-013 \mathrm{El}$ xenograft growth in vivo significantly earlier than Fulvestrant alone.

Conclusions. These findings suggest Riluzole combined with endocrine therapy may offer therapeutic benefit in diverse $\mathrm{ER}+$ breast cancers, including lobular breast cancer.

\section{Keywords}

Estrogen receptor; Riluzole; invasive lobular breast cancer; Fulvestrant

\section{Running Title}

Riluzole in ER+ Breast Cancer 
bioRxiv preprint doi: https://doi.org/10.1101/2020.07.30.227561; this version posted July 30, 2020. The copyright holder for this preprint (which

was not certified by peer review) is the author/funder, who has granted bioRxiv a license to display the preprint in perpetuity. It is made available under aCC-BY 4.0 International license.

\section{Background}

Estrogen receptor-positive $(E R+)$ breast cancer is the most commonly diagnosed cancer among women in the United States [1]. Endocrine therapies ranging from selective estrogen receptor modulators and downregulators (SERMs, SERDs) to aromatase inhibitors are the backbone of our current standard of care for clinical management of ER+ breast cancers [2]. Although these treatments have significantly improved disease-free and overall survival for individuals with ER+ breast cancer, endocrine resistance remains a persistent, multifactorial problem [3] that current efforts aim to address through combination therapy with endocrine agents plus a myriad of other molecularly targeted therapies. Further complicating these efforts is the fact that ER+ breast cancer is not a single disease. Invasive lobular breast cancer (ILC) is a distinct histologic subtype of breast cancer that is overwhelmingly ER+ yet has distinct genomic, transcriptomic and proteomic features [4-6]. These distinctions have important implications for endocrine therapy response, since when compared to the more common invasive ductal breast cancer (IDC), ILC carries a greater risk for late recurrence (evident $>6$ years after initial diagnosis) [7,8], and is less responsive to the SERM Tamoxifen [9,10] and potentially the steroidal aromatase inhibitor exemestane [11]. A recent preclinical study suggests models of ILC are less responsive to the second-generation SERD AZD9496 than Fulvestrant, while these drugs are equipotent in preclinical models of IDC [12].

Our group $[13,14]$ and others [12,15-20] have identified a number of potential mechanisms that contribute to endocrine therapy resistance in ILC. We recently identified upregulation of multiple metabotropic glutamate receptors (mGluRs, GRMs) in Tamoxifen-resistant ILC cells [14]. This, coupled with other studies that directly or indirectly implicate altered amino acid metabolism and signaling in ILC pre-clinical models [21] and clinical disease [22,23], led us to consider whether glutamate signaling is functionally relevant to endocrine resistance in this setting. Initially in melanoma [24,25], and now other malignancies [26], it has been shown that pro-tumorigenic signaling through GRMs can be inhibited by Riluzole, a benzathiole-based glutamate release inhibitor that is FDA-approved for the treatment of amyotrophic lateral sclerosis (ALS). Riluzole's proposed mechanism of action in the central nervous system in ALS and in melanoma is that, by blocking glutamate release into the extracellular space, GRMs are starved of their glutamate ligand and thus functionally inhibited; this reduces glutamate excitotoxicity and inhibits tumor cell growth, respectively. However, in breast cancer, Riluzole action is not dependent on GRMs [27,28], although GRMs are implicated in breast tumor progression and Riluzole can still exert anti-tumor effects [29-31].

ER+ breast cancer, and especially ILC, has not been a major focus for prior studies of Riluzole repurposing in cancer. Therefore, the goal of this study is to more broadly test the efficacy of Riluzole, alone and in combination with multiple endocrine therapies, in a diverse set of ER+ in vitro and in vivo models enriched for ILC. 


\section{Methods}

Cell Culture and Reagents. SUM44 and LCCTam cells were maintained under serum-free conditions in improved minimal essential media (IMEM, \#A1048901, ThermoFisher, Grand Island, NY) supplemented with insulin, hydrocortisone, and other supplements as previously described [13], with the addition of $500 \mathrm{nM}$ 4-hydroxytamoxifen (\#H7904, Sigma Aldrich, St. Louis, MO) to LCCTam cells. For selected experiments, SUM44 and LCCTam cells were maintained under serum-free conditions in a base media of Ham's F12 (\#11765062, ThermoFisher) supplemented as above. MDA-MB-134VI cells were maintained in IMEM supplemented with $5 \%$ fetal bovine serum (FBS). BCK4 cells were maintained in IMEM supplemented with $10 \%$ FBS, insulin, and nonessential amino acids as previously described [32]. MCF7 and LCC9 cells were maintained in IMEM supplemented with 5\% FBS, or phenol red-free IMEM supplemented with 5\% charcoal-cleared serum (CCS), respectively. For selected experiments, MDA-MB-134VI and MCF7 cells were short-term hormone-deprived by culturing in phenol red-free IMEM (\#A1048801, ThermoFisher) supplemented with $5 \%$ CCS for 72 hours. The immortalized mammary epithelial cell line MCF10A was maintained as previously described [33] All cell lines were authenticated by short tandem repeat (STR) profiling and regularly tested to ensure that they remained free of Mycoplasma spp. contamination. Unless otherwise noted, general cell culture supplements and reagents were purchased from either ThermoFisher or Sigma Aldrich. Fulvestrant and Riluzole were purchased from Sigma Aldrich, Tocris Bio-Techne (Minneapolis, MN) or Selleckchem (Houston, TX).

Cell Proliferation Assays. On Day 0 cells were seeded in 96-well plates at the following densities: 1,000 cells/well (MCF7); 2,000 cells/well (LCC9, MCF10A); 10,000 cells/well (SUM44, LCCTam, MDA-MB-134VI); 15,000 cells/well (BCK4). Forty eight hours later, on Day 2, cells were treated with the indicated concentration of compound(s) or solvent control (DMSO) for an additional 7 or 8 days, with media replaced and fresh compound(s) on Day 5 or 6 . Plates were then stained with crystal violet, dried, rehydrated, and read as previously described in [14]. Data are presented as mean \pm standard error of the mean (SEM, Riluzole growth curves) or median with upper/lower quartiles (effect of $10 \mu \mathrm{M}$ Riluzole on cell line pairs) of \% growth (vehicle = $100 \%$ ) for 5-6 technical replicates, and are representative of 2-4 independent biological assays. For assays of Riluzole in combination with Fulvestrant, data are presented as median with upper/lower quartiles of \% growth for 5-6 technical replicates, and are representative of 2-4 independent biological assays. For assays of Riluzole in combination with 4-hydroxytamoxifen, data are presented as the mean of \% growth for 5-6 technical replicates, and are representative of 2-4 independent biological assays.

Cell Cycle Assays. On Day 0 cells were seeded in 6-well plates at the following densities: 150,000 cells/well (MCF7, LCC9); 300,000 cells/well (SUM44, LCCTam, MDA-MB-134VI, BCK4, MCF10A). Forty eight hours later, on Day 2, cells were treated with $10 \mu \mathrm{M}$ Riluzole or DMSO control for the additional indicated times before collection, fixation, staining, and cell cycle analysis by flow cytometry as described in [34]. Data are presented as mean \pm standard deviation (SD) for 3-4 independent biological assays.

Annexin V Apoptosis Assays. On Day 0, cells were seeded in a 6-well plate at 300,000 cells/well (SUM44, LCCTam). Forty eight hours later, on Day 2, cells were treated with either $10 \mu \mathrm{M}$ Riluzole or the solvent, DMSO, as a control for an additional 48 hours. On Day 4, cells were collected and stained with $4 \mu \mathrm{L}$ of propidium iodide (PI) and $4 \mu \mathrm{L}$ of annexin $V$ conjugated with fluorescein isothiocyanate (FITC) in $100 \mu \mathrm{L}$ of $1 \mathrm{X}$ binding buffer. Control cells were either left unstained or stained with either $\mathrm{PI}$ or annexin $\mathrm{V}$ dye conjugated with FITC as described in [35]. Live $\left(\mathrm{PI}^{-}\right.$, annexin $\left.\mathrm{V}^{-}\right)$, early apoptotic $\left(\mathrm{PI}^{-}\right.$, annexin $\left.\mathrm{V}^{+}\right)$, late apoptotic $\left(\mathrm{PI}^{+}\right.$, annexin $\mathrm{V}^{+}$), and necrotic cells $\left(\mathrm{PI}^{+}\right.$, annexin $\mathrm{V}^{-}$) were quantified by flow cytometry. The PI/Annexin V-FITC apoptosis detection kit was purchased from BioLegend (\#640914, San Diego, CA, USA). Data are presented as mean \pm SD for 3 (SUM44) or 4 (LCCTam) independent biological assays. 
Human Phospho-Kinase Proteome Profiler ${ }^{\mathrm{TM}}$ Array. On Day 0, cells were seeded in a 6-well plate at 500,000 cells/well (SUM44, LCCTam). Forty eight hours later, on Day 2, cells were treated with either $10 \mu \mathrm{M}$ Riluzole or the solvent, DMSO, as a control for an additional 48 hours. On Day 4, cells were collected in $100 \mu \mathrm{L}$ lysis buffer/well prior to determining total protein concentration by bicinchoninic acid (BCA) assay (\#23225, ThermoFisher). Five hundred micrograms of whole cell lysate were then assayed using the Human Phospho-Kinase Proteome Profiler ${ }^{\mathrm{TM}}$ Array (\#ARY003B, Bio-Techne) according to manufacturer's instructions. Array membranes were visualized using chemiluminescence detected by HyBlot CL autoradiography film (\#E3018, Thomas Scientific, Swedesboro, NJ), then films were scanned and analyzed using FIJI [36]. A ratio of background-corrected intensity values for targets (phospho-kinase spots) to references (control spots) was created for each condition (DMSO and Riluzole) within each cell line. Data are presented as the mean of the Riluzole:DMSO ratio for 2 technical replicates from a single experiment for each cell line. Gene symbols corresponding to the kinases showing decreased phosphorylation in response to Riluzole in LCCTam cells were analyzed using Metascape [37] to identify top functional enrichments.

Primary Breast Tumor Explant Cultures. Patient-derived explants (PDEs) from five (5) ER+ primary breast tumors were processed and cultured as described in [38]. PDEs were treated with $100 \mathrm{nM}$ Fulvestrant, $10 \mu \mathrm{M}$ Riluzole, the combination, or solvent control (DMSO) for 48 hours prior to formalin fixation, paraffin embedding, sectioning, and staining for PCNA (1:1000, \#sc-56, SCBT, Santa Cruz, CA), cleaved caspase 3 (1:300, \#9661, Cell Signaling Technology, Danvers, MA), and Ki67 (1:500, \#ab16667, Abcam, Cambridge, MA). Stained sections were then visualized and scored as described in [38]. Data are presented as change relative to vehicle (set to 0 ) for each of the PDEs.

HCl-013 and HCl-013EI Xenograft Experiments. All animal studies were ethically conducted in accordance with our approved Institutional Animal Care and Use Committee (IACUC) protocols \#2018-0005 and \#2018-0006. For the comparison of time to tumor formation between $\mathrm{HCl}-013$ and $\mathrm{HCl}-013 \mathrm{El}$ in the presence vs. absence of supplemental estrogen pellets, twenty four (24) 5-6 week-old intact (non-ovariectomized) female non-obese diabetic, severe combined immunodeficient mice (NOD.CB17-Prkdcscid/NCrCrl, purchased from Charles River, Wilmington, MA) were orthotopically implanted in the right 4th mammary gland with a single 1-3 mm ${ }^{3}$ PDX fragment per mouse as follows: HCl-013El $(n=6)$; HCl-013El+E2 $(n=6)$; HCl-013 $(n=6)$; $\mathrm{HCl}-013+\mathrm{E} 2(\mathrm{n}=6)$. "+E2" denotes co-implantation of a $1 \mathrm{mg}$ estrogen pellet under the skin on the back between the shoulder blades. Mice were followed until measurable tumor development (by calipers), and data are presented as a survival plot with $n=6$ mice per group. For treatment studies of $\mathrm{HCl}-013 \mathrm{El}$ tumors, forty eight (48) 5-6 week-old intact (non-ovariectomized) female mice were orthotopically implanted in the right 4th mammary gland with a single 1-3 $\mathrm{mm}^{3} \mathrm{HCl}-013 \mathrm{EI}$ PDX fragment per mouse without estrogen supplementation, then followed until tumors reached $\sim 100 \mathrm{~mm}^{3}$ before enrollment to one of the four (4) treatment arms: control $(n=8), 10 \mathrm{mg}$ Fulvestrant in castor oil SQ (2 5-mg injections per week, $n=9), 10 \mathrm{mg} / \mathrm{kg}$ Riluzole PO in corn oil (5 days per week, $n=9$ ), or the combination $(n=9)$. Mice were monitored for tumor growth (measured by calipers) and body weight twice per week. Tumor volumes were calculated by the modified ellipsoid formula $V=1 / 2\left(X Y^{2}\right)$, where $X$ is the longest axis and $Y$ is the longest perpendicular axis. Tumor volume data are presented as mean \pm SEM for $n=8-9$ mice per treatment group. The baseline measurement represents the measurement at the point of enrollment to a treatment group based on the a priori tumor volume as calculated above. The subsequent measurements are those taken while on treatment at the twice per week frequency. The slope of tumor growth for each group is presented as mean \pm SD for the same tumors.

Multiplex Immunohistochemistry (mIHC) Staining. HCl-013+E2 ( $n=5)$ and $\mathrm{HCl}-013 \mathrm{El}(\mathrm{n}=4)$ tumors from mice in our PDX maintenance colony - independent from experimental animals described above - were resected, formalin fixed, paraffin embedded, then sectioned for staining on the Vectra3 multi-spectral imaging 
platform (Akoya Biosciences, Marlborough, MA) using OPAL chemistry. The slides were baked at $60^{\circ} \mathrm{C}$, deparaffinized in xylene, rehydrated, washed in tap water and incubated with $10 \%$ neutral buffered formalin for an additional 20 minutes to increase tissue-slide retention. Epitope retrieval/microwave treatment (MWT) for all antibodies was performed by boiling slides in Antigen Retrieval buffer 6 (AR6 pH6; Akoya, AR6001KT). Protein blocking was performed using antibody diluent/blocking buffer (Akoya, ARD1001EA) for 10 minutes at room temperature. Primary antibody/OPAL dye pairings and incubation conditions for ER, PR, HER2, Ki67, and pan cytokeratin staining are detailed in Table 1. MWT was performed to remove the primary and secondary antibodies between rounds of multiplex IHC. Multiplex IHC was finished with MWT and counterstained with spectral DAPI (Akoya FP1490) for 5 min and mounted with ProLong Diamond Antifade (ThermoFisher, P36961). The order of antibody staining and the antibody/OPAL pairing was predetermined using general guidelines and the particular biology of the panel. General guidelines include spectrally separating co-localizing markers and separating spectrally adjacent dyes. Multiplex IHC was optimized by first performing singleplex IHC with the chosen antibody/OPAL dye pair to optimize signal intensity values and proper cellular expression, followed by optimizing the full multiplex assay.

mIHC Imaging and Analysis. Slides were scanned at 10X magnification using the Vectra 3.0 Automated Quantitative Pathology Imaging System (PerkinElmer/Akoya,). Whole slide scans were viewed with Phenochart (Perkin Elmer/Akoya) which also allows for the selection of high-powered images at 20X (resolution of $0.5 \mathrm{~m}$ per pixel) for multispectral image capture. Multispectral images of each xenograft tissue specimen were captured in their entirety. Multispectral images were unmixed using spectral libraries built from images of single stained tissues for each reagent using the inForm Advanced Image Analysis software (inForm 2.4.6; PerkinElmer/Akoya). A selection of 10-15 representative multispectral images spanning all nine tissue sections was used to train the inForm software (tissue segmentation, cell segmentation and phenotyping tools). All the settings applied to the training images were saved within an algorithm to allow batch analysis of all the multispectral images particular to each panel. Data are presented as median with upper/lower quartiles of $\%$ marker positivity for 5-13 fields per tumor, and as overall mean \pm SD of $\%$ marker positivity for all tumors.

Statistical Analysis. Statistical analyses were performed using GraphPad Prism 8.0 (San Diego, CA) at $\alpha \leq 0.05$, except for Riluzole/4-hydroxytamoxifen combination experiments, which were analyzed by synergyfinder [39]. Single-agent Riluzole experiments were analyzed by nonlinear regression ([inhibitor] vs. normalized response), and response to $10 \mu \mathrm{M}$ Riluzole in endocrine therapy sensitive/resistant cell line pairs (SUM44 vs. LCCTam and MCF7 vs. LCC9) was compared by Mann-Whitney test. Riluzole/Fulvestrant combination experiments were analyzed by Kruskal Wallis test followed by Dunn's multiple comparison test. Riluzole/4-hydroxytamoxifen combination experiments were analyzed using the zero interaction potency (ZIP) method [40] in synergyfinder. Cell cycle experiments were analyzed by two-way Analysis of Variance (ANOVA) followed by either Sidak's (single time point) or Dunnett's (multiple time points) multiple comparisons tests. Annexin V apoptosis assays were analyzed by two-way ANOVA followed by Sidak's multiple comparisons test. Staining for each marker in primary breast tumor explant cultures was analyzed by one-sample t test vs. 0 (vehicle). In the xenograft experiment comparing time to tumor formation between $\mathrm{HCl}-013$ and $\mathrm{HCl}-013 \mathrm{El}$ in the presence vs. absence of supplemental estrogen pellets, data were analyzed by log-rank (Mantel-Cox) test. In the xenograft experiment testing Fulvestrant, Riluzole, the combination, or control in $\mathrm{HCl}-013 \mathrm{El}$, tumor volume and mouse body weight data were analyzed by mixed effects analysis followed by Dunnett's multiple comparisons tests at each timepoint vs. control, while differences in the slope of tumor growth between treatment groups was compared by Browne-Forsyth and Welch ANOVA followed by Dunnett's T3 multiple comparisons tests. mIHC data were analyzed by Mann-Whitney test. 


\section{Results}

Riluzole has shown anti-tumor activity in preclinical models of multiple cancers, including melanoma, glioblastoma, and breast cancer [25-31]. In several (but not all) of these reports, Riluzole-mediated growth inhibition is attributed to increased expression of metabotropic glutamate receptors (mGluRs, GRMs). We recently reported that acquisition of Tamoxifen resistance in a cellular model of invasive lobular breast cancer (ILC, [13]) is accompanied by the upregulation of GRM mRNA expression and growth inhibition by Riluzole [14]. Here, our goal was to more broadly test the efficacy of Riluzole, alone and in combination with multiple endocrine therapies, in a diverse set of estrogen receptor-positive $(E R+)$ in vitro and in vivo models enriched for ILC. The in vitro models used include ER+ ILC cell lines (SUM44, LCCTam, MDA-MB-134VI, and BCK4), ER+ IDC cell lines (MCF7 and LCC9), and the ER-negative (ER-) non-transformed cell line MCF10A as a control. The in vivo models include a series of ER+ patient-derived explants, and patient-derived xenografts (HCl-013 and $\mathrm{HCl} 013 \mathrm{El})$.

Growth suppression of ER+ breast cancer cell lines by Riluzole. We performed dose-response assays of Riluzole (33 nM to $100 \mu \mathrm{M}$ ) in three ILC- and two invasive ductal breast cancer (IDC)-derived cell lines, and the ER- non transformed breast epithelial cell line MCF10A, using crystal violet staining as a proxy for total cell number [14] (Figure 1A). Nonlinear regression analysis calculated the Riluzole $I_{50}$ for all six cell lines to be 10-100 $\mu \mathrm{M}$, consistent with published studies in other malignancies. Direct comparison of growth inhibition by $10 \mu \mathrm{M}$ Riluzole in two endocrine-responsive and -resistant cell line pairs (Figure 1B) confirmed [14] that the Tamoxifen-resistant ILC cell line LCCTam was significantly more responsive to Riluzole than its Tamoxifen-responsive counterpart SUM44 (Mann-Whitney test, ${ }^{* *} \mathrm{p}=0.002$ ). This was not the case for the MCF7/LCC9 IDC cell line pair [41], in which MCF7 cells showed greater Riluzole-mediated growth inhibition $\left({ }^{*} p=0.024\right)$ than Fulvestrant-resistant/Tamoxifen-cross-resistant LCC9 cells. The MDA-MB-134VI (MM134) ILC cell line showed a similar response as SUM44, while MCF10A cells were not growth inhibited by $10 \mu \mathrm{M}$ Riluzole vs. DMSO control.

Response of ER+ cell lines to growth inhibition by small molecules can be influenced by the presence vs. absence of steroid hormones and estrogenic compounds. Experiments presented in Figure 1 were, except for LCC9 cells, performed under hormone-replete conditions, so assays in selected cell lines were repeated under hormone-deprived conditions (Figure S1). The SUM44/LCCTam cell line pair is cultured in serum-free media, but a phenol red-containing base (IMEM, $10 \mathrm{mg} / \mathrm{L}$ ), while MCF7 and MM134 cells are cultured in phenol red-containing IMEM supplemented with 5\% FBS. While individual differences within cell lines were observed, hormone deprivation - reduced phenol red media for SUM44/LCCTam (Ham's F12, 1.2 mg/L) or phenol red-free IMEM supplemented with 5\% CCS for MCF7 and MM134 - did not consistently enhance or impair Riluzole-mediated growth inhibition.

Riluzole induces a histologic subtype-associated cell cycle arrest. To corroborate results of the cell proliferation assays, we tested the effect of Riluzole on cell cycle progression (Figure 2), and expanded our studies to include BCK4, a third model of ER+ ILC [32]. All ILC cell lines showed a significant accumulation of cells in G2-M phase (two-way ANOVA followed by Sidak's (single time point) or Dunnett's (multiple time points) multiple comparisons tests, see figure legend). However, both IDC-derived cell lines showed a significant accumulation of cells in G0-G1 phase, while non transformed MCF10A cells showed no significant cell cycle arrest in response to Riluzole. Together with the results presented in Figures 1 and $\mathrm{S} 1$, these data suggest that while all ER+ breast cell lines tested can be growth inhibited by Riluzole, ILC cells preferentially undergo G2-M arrest while IDC cells arrest in G0-G1.

Riluzole induces apoptosis and inhibits phosphorylation of pro-survival signaling molecules. We then performed Annexin V assays to measure the effect of Riluzole on apoptosis in the SUM44/LCCTam cell line 
pair. The percentage of live, early apoptotic, late apoptotic, and necrotic cells were measured in response to Riluzole for each cell line (Figure 3A), and the percentage of early apoptotic cells were regraphed separately (Figure 3B). LCCTam cells showed a significant increase in the percent of cells in early apoptosis when treated with Riluzole (two-way ANOVA followed by Sidak's multiple comparisons test, ${ }^{* * * *} p<0.0001$ ), but SUM44 cells did not. These data are consistent with those presented in Figure 1B, which show that LCCTam cells were significantly more growth-inhibited by Riluzole than SUM44 cells.

To identify molecular signaling events that accompany Riluzole-mediated apoptosis in the SUM44/LCCTam cell line pair, we used the Human Phospho-Kinase Proteome Profiler ${ }^{\mathrm{TM}}$ Array to detect changes in 43 phosphorylation sites across 40 different kinases or substrates (Figure 3C). In SUM44 cells, Riluzole reduced phosphorylation of mutant p53 [42] (S92 and S392), and Akt T308. In LCCTam cells, Riluzole reduced phosphorylation of markedly more sites, in kinases and substrates with significantly enriched ontology clusters including EGFR (ERBB1) and MET signaling, and cellular response to hormone stimulus (Figure S2A). Notable inhibition of Akt/mTOR (Akt S437, TOR S2448, PRAS40 T246), CREB (Msk S376/360, CREB S133), and Src/Fak (Lyn Y397, Yes Y426, Fak Y397, Figure S2B) signaling pathways was observed specifically in LCCTam cells. Prior studies in melanoma and glioblastoma have shown that Riluzole inhibits Akt phosphorylation, and that Riluzole combined with mTOR inhibition can synergistically decrease xenograft growth $[26,43]$. However, inhibition of Src/Fak family kinases has not to our knowledge been previously reported.

Additive/synergistic suppression of ER+ breast cancer cell line growth by Riluzole in combination with endocrine therapies. Endocrine therapies ranging from selective estrogen receptor modulators and downregulators (SERMs, SERDs) to aromatase inhibitors represent the standard of care for clinical management of ER+ breast cancers [2]. We therefore tested the activity of Riluzole in combination with the SERD Fulvestrant or SERM Tamoxifen (4-hydroxytamoxifen) in ILC- and IDC-derived ER+ breast cancer cell lines, and the ER- non transformed breast epithelial cell line MCF10A as a negative control. These experiments were conducted under hormone-replete conditions. In the ILC-derived SUM44, LCCTam, MM134, and BCK4 cell lines, the combination of Fulvestrant plus Riluzole caused significantly additive or better growth inhibition (Figure 4, Kruskal Wallis test followed by Dunn's multiple comparison test, see figure legend). In the IDC-derived MCF7 cell line, Fulvestrant alone was highly effective, so the addition of Riluzole caused no further decrease in cell growth. LCC9 cells were resistant to Fulvestrant, and the combination of Fulvestrant plus Riluzole was not better than Riluzole alone. MCF10A cells were not significantly growth-inhibited by either drug or the combination. Combinations of 4-hydroxytamoxifen and Riluzole (Figure S3) were moderately to strongly synergistic $[39,40]$ in SUM44, LCCTam, and MCF7 cells, but not LCC9 cells. MCF10A cells were again not significantly growth-inhibited by either drug or the combination. Altogether, these data suggest that the combination of endocrine therapy and Riluzole can additively or synergistically suppress the growth of a variety of ER+ breast cancer cell line models.

\section{Riluzole plus Fulvestrant inhibits proliferation in primary breast tumor explant cultures. There are} limitations to pre-clinical testing of combination therapies in two-dimensional (2D) cell culture models on tissue culture plastic using established cell lines. Patient-derived explants (PDEs) allow medium-throughput testing of short-term response to therapeutic agents in fragments of fresh tumor tissue, thereby overcoming some of these limitations. Specifically, PDEs capture and preserve the initial tissue architecture, tumor microenvironment, and inter-person heterogeneity [38]. We tested the efficacy of Fulvestrant, Riluzole, or the combination vs. solvent control (DMSO) in five (5) PDEs from ER+/PR+/HER2-negative primary tumors (Figure 5A). Using proliferating cell nuclear antigen (PCNA) staining as a proxy for cell proliferation, the combination of Riluzole plus Fulvestrant significantly reduced PCNA (Figures 5B and 5C, one-sample t test vs. 0 (Vehicle), ${ }^{*} p=0.013$ Vehicle vs. Combination), with 4 of 5 PDEs showing better growth inhibition by the combination than either drug alone. Staining for Ki67 was inconsistent in response to either drug alone or the 
combination, while staining for cleaved caspase 3 suggested a modest induction of apoptosis by either drug alone or the combination in some of the PDEs (Figure S4).

Riluzole plus Fulvestrant inhibits HCl-013El tumor growth earlier than Fulvestrant alone. Patient-derived xenografts (PDXs) provide a second clinically relevant alternative to $2 \mathrm{D}$ culture models for pre-clinical testing of combination therapies. The HCl-013 PDX model was established from a 53 year-old woman with metastatic, multi-therapy-resistant ER+/PR+/HER2- ILC by serial passage through intact (non-ovariectomized) female NOD scid gamma (NSG) mice supplemented with a $1 \mathrm{mg}$ estrogen (E2, 17ß-estradiol) pellet [15]. The $\mathrm{HCl}-013 \mathrm{El}$ (estrogen-independent) variant was established by two weeks of in vitro culture of cells from $\mathrm{HCl}-013$ tumors under hormone-deprived conditions, then reimplanted into intact female NSG mice without estrogen supplementation. Both models harbor the clinically relevant ESR1 activating mutation Y537S, with the $\mathrm{HCl}-013 \mathrm{El}$ variant reported to have a more abundant variant allele fraction of Y537S.

To directly compare the responsiveness to, and requirement for, supplemental estrogen of $\mathrm{HCl}-013$ vs. $\mathrm{HCl}-013 \mathrm{El}$ in our hands, six (6) 5-6 week-old intact (non-ovariectomized) severe combined immunodeficient (SCID) female mice per group were orthotopically implanted with a single 1-3 $\mathrm{mm}^{3}$ PDX fragment, then followed until tumor development measurable by calipers (Figure 6A). In the presence of supplemental estrogen pellets, $\mathrm{HCl}-013$ and $\mathrm{HCl}-013 \mathrm{El}$ both exhibited a $100 \%$ tumor take rate, with a median time to tumor formation of 23.5 and 26.5 days, respectively. However, in the absence of supplemental estrogen pellets, $\mathrm{HCl}-013 \mathrm{PDX}$ fragments were unable to form tumors out to 113 days post implantation, while HCI-013EI PDX fragments exhibited a $50 \%$ tumor take rate, with a median time to tumor formation of 39 days (log-rank Mantel-Cox test, ${ }^{* * *} \mathrm{p}=0.0007$ ). These data suggest that supplemental estrogen is necessary for $\mathrm{HCl}-013$ tumor formation, and beneficial but not necessary for $\mathrm{HCl}-013 \mathrm{El}$ tumor formation, in SCID mice.

We characterized an independent set of $\mathrm{HCl}-013+\mathrm{E} 2$ (estrogen supplemented, n=5) and $\mathrm{HCl}-013 \mathrm{EI}$ (not estrogen supplemented, n=4) tumors with respect to ER, PR, HER2, and Ki67 expression using Opal chemistries on the Vectra3 multi-spectral imaging platform (Figures 6B and 6C). This approach captured heterogeneity in marker expression between and within tumors. Overall, percent ER positivity (\% ER+) was significantly lower in $\mathrm{HCl}-013 \mathrm{El}$ vs. $\mathrm{HCl}-013+\mathrm{E} 2$ tumors (Mann-Whitney test, ${ }^{*} \mathrm{p}=0.032$ ), consistent with a prior report that Y537S mutant ER protein expression can be lower than wild type ER [44]. However, overall percent PR and Ki67 positivity was not significantly different between these PDX variants. No HER2 staining was detected.

We moved forward with the $\mathrm{HCl}-013 \mathrm{El}$ (not estrogen supplemented) PDX variant to test the anti-tumor activity of Fulvestrant, Riluzole, or the combination relative to vehicle control. Forty eight (48) 5-6 week-old intact SCID female mice were orthotopically implanted with a single 1-3 $\mathrm{mm}^{3} \mathrm{HCl}-013 \mathrm{EI}$ PDX fragment without E2 supplementation, then followed until tumors reached $\sim 100 \mathrm{~mm}^{3}$ before enrollment to one of four (4) treatment arms: control $(n=8)$, Fulvestrant $(n=9)$, Riluzole $(n=9)$, or the combination $(n=9)$ (Figures 6D and S5A). Relative to control, single-agent Riluzole had no effect on tumor volume. Single-agent Fulvestrant and the combination of Fulvestrant plus Riluzole were similarly effective, as both significantly slowed the increase in tumor volume. However, combination treatment yielded a statistically significant growth delay earlier (Measurement 2, Day 7) than Fulvestrant alone (Measurement 5, Day 17, mixed effects analysis followed by Dunnett's multiple comparisons tests at each timepoint vs. control, see figure legend). Comparison of the slope of tumor growth for the treatment groups further demonstrated a statistically significant difference between Fulvestrant- vs. combination-treated tumors (Figure 6E, Browne-Forsyth and Welch ANOVA followed by Dunnett's T3 multiple comparisons tests, * $p=0.023$ ), with combination-treated tumors having a more negative slope suggestive of greater tumor shrinkage. Analysis of mouse body weights between the treatment groups showed that there were no significant differences between treatment groups. As seen in Figure S5B, the slope of the graphs for each treatment group is close to zero. Together with the results presented in Figures 4, 5, and accompanying supplementary figures, these data suggest that the combination of Fulvestrant and Riluzole may offer improved therapeutic benefit in ER+ breast cancer. 


\section{Discussion}

We tested the efficacy of Riluzole, alone and in combination with multiple endocrine therapies, in a diverse set of estrogen receptor-positive $(\mathrm{ER}+)$ in vitro and in vivo models enriched for ILC. Single-agent Riluzole suppressed the growth of ER+ ILC and IDC cell lines in vitro, inducing a histologic subtype-associated cell cycle arrest (G0-G1 for IDC, G2-M for ILC). In the Tamoxifen-resistant ILC-derived LCCTam model, Riluzole induced apoptosis and reduced phosphorylation of multiple pro-survival signaling molecules, including Akt/mTOR, CREB, and Src/Fak family kinases. Riluzole in combination with either Fulvestrant or 4-hydroxytamoxifen additively or synergistically suppressed ER+ breast cancer cell growth in vitro. The combination of Riluzole plus Fulvestrant significantly reduced proliferation in primary breast tumor explant cultures, and inhibited HCl-013EI ILC PDX growth in vivo significantly earlier than Fulvestrant alone.

The increased combinatorial efficacy of Riluzole and Fulvestrant we observe across diverse cell line models of ER+ breast cancer in vitro is recapitulated in vivo, using primary tumor explant cultures (PDEs) and (to a lesser extent) the ILC-derived HCl-013EI PDX. In the PDX experiment, tumor volume after $\sim 4$ weeks of treatment was not significantly different in combination- vs. Fulvestrant-tumors, which we attribute to the good responsiveness of this PDX to Fulvestrant demonstrated in this experiment and by others [45,46]. It should be noted, however, that these published studies report Fulvestrant responsiveness of $\mathrm{HCl}-013$, and not specifically $\mathrm{HCl}-013 \mathrm{El}$. However, the combination of Riluzole and Fulvestrant led to a significant growth inhibition vs. control $\sim 10$ days earlier than Fulvestrant alone, and inspection of the individual volume trajectories for each tumor shows more consistent suppression in the combination group as compared to Fulvestrant alone (Figure S5A). Furthermore, the slope of tumor growth for the combination was more strongly negative (-4.174, suggestive of tumor shrinkage) and significantly reduced vs. Fulvestrant monotherapy $(-1.69$, Figure 6E). In the PDE experiment, the combination of Riluzole and Fulvestrant was more effective than in the PDXs, with $80 \%$ of primary tumor explants (4/5) showing significant growth inhibition by the combination as measured by a reduction in PCNA (Figure 5), but not Ki67 (Figure S4). Improved combinatorial efficacy may be due to the lower concentration of Fulvestrant used in these studies (100 nM), so future in vivo studies with the $\mathrm{HCl}$-013EI PDX will adopt this approach (i.e. a lower dose of Fulvestrant, as in [45], alone and in combination with Riluzole). A second contributor to improved combinatorial efficacy in the PDE vs. PDX experiment may be Riluzole bioavailability and metabolism (see below). The discrepancy in response to treatment for the PCNA and Ki67 measures is likely due to the fact that baseline Ki67 positivity in vehicle-treated PDEs is low (3.8\% $-11.6 \%$ ), which limits the effective range of an assay designed to measure a (further) decrease in Ki67. By contrast, baseline PCNA expression is robust (48.2\%-92.8\%), so decreases in expression may be more readily detected. An alternative or complementary explanation is that Riluzole induces G2-M arrest in most malignancies tested, and in all of our ER+ ILC cell lines, but a G0-G1 arrest in the ER+ MCF7-derived IDC cell lines (Figure 2). Riluzole's tendency to induce G2-M arrest may partly explain why a reduction in Ki67 is not observed, since Ki67 expression accumulates in the S through M phases of the cell cycle [47], while by contrast PCNA expression is maximal in late $\mathrm{G} 1$ and $\mathrm{S}$ phases.

In the Tamoxifen-resistant ILC-derived LCCTam model, Riluzole induces apoptosis concomitant with reduced phosphorylation of multiple pro-survival signaling molecules. That these include components of the Akt/mTOR signaling pathway (Akt S437, TOR S2448, PRAS40 T246) is not surprising, since Riluzole has been shown to inhibit Akt phosphorylation and synergize with mTOR inhibition in melanoma and glioblastoma models [26,43]. However, Src/Fak kinase family members Lyn, Yes, and Fak have not, to our knowledge, been previously implicated in Riluzole action. In vehicle-treated LCCTam cells, baseline phosphorylation of these kinases is increased (Lyn Y397 1.75-fold, Fak Y397 1.6-fold, Yes Y426 1.85-fold) as compared to vehicle-treated SUM44 cells, and each of these sites is markedly dephosphorylated in response to Riluzole treatment only in LCCTam cells, with Yes Y426 showing the largest Riluzole-induced decrease ( 3-fold, Figure S2B). All three of these 
Src/Fak kinase family members are closely connected to cell survival, invasion and migration, while Lyn and Fak have also been previously implicated in endocrine therapy resistance [48,49]. Being functionally E-cadherin-negative, ILC is particularly resistant to anoikis (a form of cell death induced by extracellular matrix detachment) [50], and becomes highly dependent upon a rewired actin cytoskeleton and constitutive actomyosin contractility (reviewed in [51]). A notable downstream target of Yes whose function is also tightly regulated by actin dynamics (Yes-associated protein 1, YAP1) is more frequently activated and localized to the nucleus in ILC [52], and our reanalysis of The Cancer Genome Atlas (TCGA) reverse phase protein array data $[53,54]$ confirms that total YAP1 expression is significantly increased in ER+ ILC vs. IDC ( $\log _{2}$ fold-change 0.21 , q-value $4.4 \mathrm{e}-6)$. The role of Yes or YAP1 in Riluzole-mediated growth inhibition and apoptosis remains to be explored and will be a component of future studies, as will the role of Yes/YAP1 and other Src/Fak family kinases in the additive or synergistic growth suppression achieved by the combination of Riluzole and either Fulvestrant or 4-hydroxytamoxifen. In the PDE experiment, staining for cleaved caspase 3 demonstrates a modest induction of apoptosis by either drug alone or the Riluzole-Fulvestrant combination in some of the PDEs (Figure S4), with the ILC PDE (\#1055) exhibiting apoptosis only when treated with the combination.

This study has limitations that are important to consider. First, hormone responsive ER+ models, particularly of ILC, are limited. In this study we used three of the four well-established ER+, hormone responsive ILC lines [50], the ILC-derived HCl-013EI PDX model [15], and one of five PDEs originated from ILC. Importantly, in each of the ILC models tested, Riluzole plus Fulvestrant provided greater growth inhibition or earlier tumor growth suppression than single-agent Fulvestrant. Expansion of the PDE approach will be an important strategy for rapidly diversifying the repertoire of preclinical ILC models to test this and other novel endocrine therapy combinations, essential for a breast cancer subtype that has a significantly greater risk of late recurrence, and worse response to Tamoxifen and the second-generation SERD AZD9496 [12]. A second limitation is that Riluzole bioavailability is variable, leading to mixed efficacy in preclinical and clinical studies. Here (Figure 6D) and in other preclinical studies of triple negative breast cancer [30] and glioblastoma [26], single-agent Riluzole does not have significant anti-tumor activity in vivo, while in preclinical studies of melanoma [24,25,55], Riluzole is active as a single agent. Serum levels of the drug vary widely in ALS patients receiving the drug, and in a phase II trial for advanced melanoma, circulating Riluzole concentrations also exhibited marked inter-patient variability [56]. Next-generation Riluzole analogs or prodrugs, e.g. [57], may ultimately offer better bioavailability by reducing first-pass metabolism by CYP1A2, and these will be important to explore in combination with endocrine therapy. Finally, Riluzole's multiple proposed or confirmed mechanisms of action - ranging from inhibition of signaling through GRMs [24] and glutamate release via the cystine-glutamate antiporter $x_{c}^{-}$[58] to blockade of voltage-gated sodium channels [59] and inhibition of internal ribosome entry site (IRES)-mediated protein synthesis [26] - present a third limitation to readily identifying patients who would benefit most from the drug. Some of this variability is cancer type-specific, with Riluzole action tightly coupled to GRM expression in melanoma [24] and to some extent glioblastoma [26], but not in triple negative breast cancer $[27,28]$. The many interconnected pathways of glutamate release, uptake and signaling, while reasonably well-defined in the central nervous system, remain understudied in epithelial cells and their pathologies. We posit that future preclinical studies of Riluzole in this context (epithelial tumors generally, and ER+ ILC more specifically) should address these limitations. 
bioRxiv preprint doi: https://doi.org/10.1101/2020.07.30.227561; this version posted July 30, 2020. The copyright holder for this preprint (which was not certified by peer review) is the author/funder, who has granted bioRxiv a license to display the preprint in perpetuity. It is made available under aCC-BY 4.0 International license.

\section{Conclusions}

Our data suggest Riluzole together with endocrine therapy may offer therapeutic benefit in ER+ breast cancers, including ILC, and support optimization and further investigation of such combinations in this setting. 


\section{List of Abbreviations}

ER+: estrogen receptor-positive

SERM: selective estrogen receptor modulator

SERD: selective estrogen receptor downregulator

ILC: invasive lobular breast cancer

IDC: invasive ductal breast cancer

mGluR, GRM: metabotropic glutamate receptor

ALS: amyotrophic lateral sclerosis

IMEM: improved minimal essential media

FBS: fetal bovine serum

CCS: charcoal-cleared serum

STR: short tandem repeat

DMSO: dimethylsulfoxide

SEM: standard error of the mean

SD: standard deviation

PI: propidium iodide

FITC: fluorescein isothiocyanate

BCA: bicinchoninic acid

PDE: patient-derived explant

PCNA: proliferating cell nuclear antigen

IACUC: institutional animal care and use committee

PDX: patient-derived xenograft

E2: estradiol

SQ: subcutaneous

PO: per os, by mouth

mIHC: multiplex immunohistochemistry

MWT: microwave treatment

AR6: antigen retrieval buffer 6

DAPI: 4',6-diamidino-2-phenylindole

ZIP: zero interaction potency

ANOVA: analysis of variance

MM134: MDA-MB-134VI cell line

2D: two-dimensional

NSG: NOD scid gamma

SCID: severe combined immunodeficiency

YAP1: Yes-associated protein 1

TCGA: The Cancer Genome Atlas

IRES: internal ribosome entry site 
bioRxiv preprint doi: https://doi.org/10.1101/2020.07.30.227561; this version posted July 30, 2020. The copyright holder for this preprint (which

was not certified by peer review) is the author/funder, who has granted bioRxiv a license to display the preprint in perpetuity. It is made available under aCC-BY 4.0 International license.

\section{Declarations}

Ethics approval and consent to participate. All animal studies were ethically conducted in accordance with our approved Institutional Animal Care and Use Committee (IACUC) protocols \#2018-0005 and \#2018-0006. For explant experiments, tissues were collected from discarded surgical samples from UT Southwestern Medical Center (UTSW, Dallas, TX) patients for research purposes after obtaining the written informed consent and in accordance with institutional review board-approved protocol (STU-032011-187).

Consent for publication. Not applicable.

Availability of data and materials. All data generated or analyzed during this study are included in this published article and its supplementary information files.

Competing interests. The authors declare that they have no competing interests.

Funding. These studies were supported by the Department of Defense (DoD) Breast Cancer Research Program award W81XWH-17-1-0615 to RBR. Fellowship support for HS was provided by the Tumor Biology Training Grant T32 CA009686 (principal investigator (PI): Dr. Anna T. Riegel). SP received a Georgetown Undergraduate Research Opportunities Program (GUROP) Summer Fellowship. Technical services were provided by the GUMC Animal Models, Flow Cytometry and Cell Sorting, Histopathology and Tissue, and Tissue Culture Shared Resources, which are supported, in part, by NIH/NCl Cancer Center Support Grant P30 CA051008 (PI: Dr. Louis M. Weiner). The content of this article is the sole responsibility of the authors and does not represent the official views of the DoD or $\mathrm{NIH}$.

Authors' contributions. HS and AOO contributed to study design, performed and analyzed experiments, and played a key role in writing the manuscript. SM contributed to study design, and performed and analyzed experiments. SP performed and analyzed experiments, and played a key role in writing the manuscript. YG, MIC, and CB performed and analyzed experiments. AR, HC, and DLB contributed to study design, and performed and analyzed experiments. BMJ and GVR contributed to study design. RBR contributed to study design, performed and analyzed experiments, and played a key role in writing the manuscript. All authors read and approved the final manuscript.

Acknowledgements. The authors would like to thank members of the Riggins laboratory, Drs. Karen Creswell, Michael Johnson, Marc Lippman, and Dan Xun (Lombardi Comprehensive Cancer Center, Georgetown University), and Drs. David Lum and Alana Welm (Huntsman Cancer Institute, University of Utah) for sharing reagents, scientific insights, technical assistance, and/or editorial comments on the manuscript. 
bioRxiv preprint doi: https://doi.org/10.1101/2020.07.30.227561; this version posted July 30, 2020. The copyright holder for this preprint (which was not certified by peer review) is the author/funder, who has granted bioRxiv a license to display the preprint in perpetuity. It is made available under aCC-BY 4.0 International license.

\section{References}

1. Siegel RL, Miller KD, Jemal A. Cancer statistics, 2020. CA Cancer J Clin. 2020/01/09 ed. 2020;70:7-30. 2. Burstein HJ, Lacchetti C, Anderson H, Buchholz TA, Davidson NE, Gelmon KA, et al. Adjuvant Endocrine Therapy for Women With Hormone Receptor-Positive Breast Cancer: ASCO Clinical Practice Guideline Focused Update. J Clin Oncol Off J Am Soc Clin Oncol. 2019;37:423-38.

3. Hanker AB, Sudhan DR, Arteaga CL. Overcoming Endocrine Resistance in Breast Cancer. Cancer Cell. 2020;37:496-513.

4. Ciriello G, Gatza ML, Beck AH, Wilkerson MD, Rhie SK, Pastore A, et al. Comprehensive Molecular Portraits of Invasive Lobular Breast Cancer. Cell. 2015;163:506-19.

5. Desmedt C, Zoppoli G, Gundem G, Pruneri G, Larsimont D, Fornili M, et al. Genomic Characterization of Primary Invasive Lobular Breast Cancer. J Clin Oncol. 2016;34:1872-81.

6. Michaut M, Chin SF, Majewski I, Severson TM, Bismeijer T, de Koning L, et al. Integration of genomic, transcriptomic and proteomic data identifies two biologically distinct subtypes of invasive lobular breast cancer. Sci Rep. 2016;6:18517.

7. Pestalozzi BC, Zahrieh D, Mallon E, Gusterson BA, Price KN, Gelber RD, et al. Distinct clinical and prognostic features of infiltrating lobular carcinoma of the breast: combined results of 15 International Breast Cancer Study Group clinical trials. J Clin Oncol. 2008;26:3006-14.

8. Adachi Y, Ishiguro J, Kotani H, Hisada T, Ichikawa M, Gondo N, et al. Comparison of clinical outcomes between luminal invasive ductal carcinoma and luminal invasive lobular carcinoma. BMC Cancer. 2016;16:248. 9. Metzger Filho O, Giobbie-Hurder A, Mallon E, Gusterson B, Viale G, Winer EP, et al. Relative Effectiveness of Letrozole Compared With Tamoxifen for Patients With Lobular Carcinoma in the BIG 1-98 Trial. J Clin Oncol. 2015;33:2772-9.

10. Knauer M, Gruber C, Dietze O, Greil R, Stoger H, Rudas M, et al. Abstract S2-06: Survival advantage of anastrozol compared to tamoxifen for lobular breast cancer in the ABCSG-8 study. Cancer Res; 2015. p. Abstract numer S2-06.

11. Strasser-Weippl K, Sudan G, Ramjeesingh R, Shepherd L, et al. Outcomes of invasive ductal (ID) or invasive lobular (IL) early stage breast cancer in women treated with anastrozole or exemestane in the Canadian cancer trials Group MA.27. J Clin Oncol; 2016. p. suppl; abstr 521.

12. Sreekumar S, Levine KM, Sikora MJ, Chen J, Tasdemir N, Carter D, et al. Differential regulation and targeting of estrogen receptor a turnover in invasive lobular breast carcinoma. Endocrinology. 2020; 13. Riggins RB, Lan JP, Zhu Y, Klimach U, Zwart A, Cavalli LR, et al. ERRgamma Mediates Tamoxifen Resistance in Novel Models of Invasive Lobular Breast Cancer. Cancer Res. 2008;68:8908-17. 14. Stires H, Heckler MM, Fu X, Li Z, Grasso CS, Quist MJ, et al. Integrated molecular analysis of Tamoxifen-resistant invasive lobular breast cancer cells identifies MAPK and GRM/mGluR signaling as therapeutic vulnerabilities. Mol Cell Endocrinol. 2017/09/25 ed. 2018;471:105-17.

15. Sikora MJ, Cooper KL, Bahreini A, Luthra S, Wang G, Chandran UR, et al. Invasive lobular carcinoma cell lines are characterized by unique estrogen-mediated gene expression patterns and altered tamoxifen response. Cancer Res. 2014/01/14 ed. 2014;74:1463-74.

16. Sikora MJ, Jacobsen BM, Levine K, Chen J, Davidson NE, Lee AV, et al. WNT4 mediates estrogen receptor signaling and endocrine resistance in invasive lobular carcinoma cell lines. Breast Cancer Res. 2016;18:92.

17. Sokol ES, Feng YX, Jin DX, Basudan A, Lee AV, Atkinson JM, et al. Loss of function of NF1 is a mechanism of acquired resistance to endocrine therapy in lobular breast cancer. Ann Oncol Off $\mathrm{J}$ Eur Soc Med Oncol. 2019;30:115-23.

18. Bossart EA, Tasdemir N, Sikora MJ, Bahreini A, Levine KM, Chen J, et al. SNAIL is induced by tamoxifen and leads to growth inhibition in invasive lobular breast carcinoma. Breast Cancer Res Treat.

2019;175:327-37.

19. Levine KM, Priedigkeit N, Basudan A, Tasdemir N, Sikora MJ, Sokol ES, et al. FGFR4 overexpression and hotspot mutations in metastatic ER+ breast cancer are enriched in the lobular subtype. NPJ Breast Cancer.

2019;5:19.

20. Du T, Sikora MJ, Levine KM, Tasdemir N, Riggins RB, Wendell SG, et al. Key regulators of lipid metabolism drive endocrine resistance in invasive lobular breast cancer. Breast Cancer Res BCR. 
2018;20:106.

21. Du T, Zhu L, Levine KM, Tasdemir N, Lee AV, Vignali DAA, et al. Invasive lobular and ductal breast carcinoma differ in immune response, protein translation efficiency and metabolism. Sci Rep. 2018;8:7205. 22. Ulaner GA, Goldman DA, Gönen M, Pham H, Castillo R, Lyashchenko SK, et al. Initial Results of a Prospective Clinical Trial of 18F-Fluciclovine PET/CT in Newly Diagnosed Invasive Ductal and Invasive Lobular Breast Cancers. J Nucl Med Off Publ Soc Nucl Med. 2016;57:1350-6.

23. Ulaner GA, Goldman DA, Corben A, Lyashchenko SK, Gönen M, Lewis JS, et al. Prospective Clinical Trial of 18F-Fluciclovine PET/CT for Determining the Response to Neoadjuvant Therapy in Invasive Ductal and Invasive Lobular Breast Cancers. J Nucl Med Off Publ Soc Nucl Med. 2017;58:1037-42.

24. Namkoong J, Shin S-S, Lee HJ, Marín YE, Wall BA, Goydos JS, et al. Metabotropic glutamate receptor 1 and glutamate signaling in human melanoma. Cancer Res. 2007;67:2298-305.

25. Khan AJ, Wall B, Ahlawat S, Green C, Schiff D, Mehnert JM, et al. Riluzole enhances ionizing radiation-induced cytotoxicity in human melanoma cells that ectopically express metabotropic glutamate receptor 1 in vitro and in vivo. Clin Cancer Res Off J Am Assoc Cancer Res. 2011;17:1807-14.

26. Benavides-Serrato A, Saunders JT, Holmes B, Nishimura RN, Lichtenstein A, Gera J. Repurposing Potential of Riluzole as an ITAF Inhibitor in mTOR Therapy Resistant Glioblastoma. Int J Mol Sci. 2020;21. 27. Speyer CL, Nassar MA, Hachem AH, Bukhsh MA, Jafry WS, Khansa RM, et al. Riluzole mediates anti-tumor properties in breast cancer cells independent of metabotropic glutamate receptor-1. Breast Cancer Res Treat. 2016;157:217-28.

28. Dolfi SC, Medina DJ, Kareddula A, Paratala B, Rose A, Dhami J, et al. Riluzole exerts distinct antitumor effects from a metabotropic glutamate receptor 1-specific inhibitor on breast cancer cells. Oncotarget. 2017;8:44639-53.

29. Banda M, Speyer CL, Semma SN, Osuala KO, Kounalakis N, Torres Torres KE, et al. Metabotropic glutamate receptor-1 contributes to progression in triple negative breast cancer. PLoS One. 2014;9:e81126. 30. Speyer CL, Bukhsh MA, Jafry WS, Sexton RE, Bandyopadhyay S, Gorski DH. Riluzole synergizes with paclitaxel to inhibit cell growth and induce apoptosis in triple-negative breast cancer. Breast Cancer Res Treat. 2017;166:407-19.

31. Teh JL, Shah R, La Cava S, Dolfi SC, Mehta MS, Kongara S, et al. Metabotropic glutamate receptor 1 disrupts mammary acinar architecture and initiates malignant transformation of mammary epithelial cells. Breast Cancer Res Treat. 2015/04/10 ed. 2015;151:57-73.

32. Jambal P, Badtke MM, Harrell JC, Borges VF, Post MD, Sollender GE, et al. Estrogen switches pure mucinous breast cancer to invasive lobular carcinoma with mucinous features. Breast Cancer Res Treat. 2013;137:431-48.

33. Heckler MM, Zeleke TZ, Divekar SD, Fernandez AI, Tiek DM, Woodrick J, et al. Antimitotic activity of DY131 and the estrogen-related receptor beta 2 (ERRß2) splice variant in breast cancer. Oncotarget.

2016;7:47201-20.

34. Tiek DM, Khatib SA, Trepicchio CJ, Heckler MM, Divekar SD, Sarkaria JN, et al. Estrogen-related receptor $\beta$ activation and isoform shifting by cdc2-like kinase inhibition restricts migration and intracranial tumor growth in glioblastoma. FASEB J Off Publ Fed Am Soc Exp Biol. 2019;33:13476-91.

35. Heckler MM, Riggins RB. ERRß splice variants differentially regulate cell cycle progression. Cell Cycle. 2015;14:31-45.

36. Schindelin J, Arganda-Carreras I, Frise E, Kaynig V, Longair M, Pietzsch T, et al. Fiji: an open-source platform for biological-image analysis. Nat Methods. Nature Publishing Group; 2012;9:676-82.

37. Zhou Y, Zhou B, Pache L, Chang M, Khodabakhshi AH, Tanaseichuk O, et al. Metascape provides a biologist-oriented resource for the analysis of systems-level datasets. Nat Commun. 2019;10:1523.

38. Centenera MM, Hickey TE, Jindal S, Ryan NK, Ravindranathan P, Mohammed H, et al. A patient-derived explant (PDE) model of hormone-dependent cancer. Mol Oncol. 2018/08/18 ed. 2018;12:1608-22.

39. lanevski A, Giri AK, Aittokallio T. SynergyFinder 2.0: visual analytics of multi-drug combination synergies. Nucleic Acids Res. 2020;

40. Yadav B, Wennerberg K, Aittokallio T, Tang J. Searching for Drug Synergy in Complex Dose-Response Landscapes Using an Interaction Potency Model. Comput Struct Biotechnol J. 2015;13:504-13.

41. Brünner N, Boysen B, Jirus S, Skaar TC, Holst-Hansen C, Lippman J, et al. MCF7/LCC9: an antiestrogen resistant MCF-7 variant in which acquired resistance to the steroidal antiestrogen ICI 182,780 confers an early 
crossresistance to the non-steroidal antiestrogen tamoxifen. Cancer Res. 1997;57:3486-93.

42. Wasielewski M, Elstrodt F, Klijn JG, Berns EM, Schutte M. Thirteen new p53 gene mutants identified among 41 human breast cancer cell lines. Breast Cancer ResTreat. 2006;99:97-101.

43. Rosenberg SA, Niglio SA, Salehomoum N, Chan JL-K, Jeong B-S, Wen Y, et al. Targeting Glutamatergic Signaling and the PI3 Kinase Pathway to Halt Melanoma Progression. Transl Oncol. 2015;8:1-9.

44. Bahreini A, Li Z, Wang P, Levine KM, Tasdemir N, Cao L, et al. Mutation site and context dependent effects of ESR1 mutation in genome-edited breast cancer cell models. Breast Cancer Res. 2017;19:60.

45. Guan J, Zhou W, Hafner M, Blake RA, Chalouni C, Chen IP, et al. Therapeutic Ligands Antagonize Estrogen Receptor Function by Impairing Its Mobility. Cell. 2019/07/30 ed. 2019;178:949-963 e18.

46. Ponnusamy S, Asemota S, Schwartzberg LS, Guestini F, McNamara KM, Pierobon M, et al. Androgen Receptor Is a Non-canonical Inhibitor of Wild-Type and Mutant Estrogen Receptors in Hormone Receptor-Positive Breast Cancers. iScience. 2019/11/08 ed. 2019;21:341-58.

47. Juríková M, Danihel L', Polák Š, Varga I. Ki67, PCNA, and MCM proteins: Markers of proliferation in the diagnosis of breast cancer. Acta Histochem. 2016;118:544-52.

48. Hiscox S, Barnfather P, Hayes E, Bramble P, Christensen J, Nicholson RI, et al. Inhibition of focal adhesion kinase suppresses the adverse phenotype of endocrine-resistant breast cancer cells and improves endocrine response in endocrine-sensitive cells. Breast Cancer Res Treat. 2011;125:659-69.

49. Schwarz LJ, Fox EM, Balko JM, Garrett JT, Kuba MG, Estrada MV, et al. LYN-activating mutations mediate antiestrogen resistance in estrogen receptor-positive breast cancer. J Clin Invest. 2014;124:5490-502.

50. Tasdemir N, Bossart EA, Li Z, Zhu L, Sikora MJ, Levine KM, et al. Comprehensive Phenotypic Characterization of Human Invasive Lobular Carcinoma Cell Lines in 2D and 3D Cultures. Cancer Res. 2018;78:6209-22.

51. Bruner HC, Derksen PWB. Loss of E-Cadherin-Dependent Cell-Cell Adhesion and the Development and Progression of Cancer. Cold Spring Harb Perspect Biol. 2018;10.

52. Vlug EJ, van de Ven RAH, Vermeulen JF, Bult P, van Diest PJ, Derksen PWB. Nuclear localization of the transcriptional coactivator YAP is associated with invasive lobular breast cancer. Cell Oncol Dordr.

2013;36:375-84.

53. Cerami E, Gao J, Dogrusoz U, Gross BE, Sumer SO, Aksoy BA, et al. The cBio cancer genomics portal: an open platform for exploring multidimensional cancer genomics data. Cancer Discov. 2012;2:401-4.

54. Gao J, Aksoy BA, Dogrusoz U, Dresdner G, Gross B, Sumer SO, et al. Integrative analysis of complex cancer genomics and clinical profiles using the cBioPortal. Sci Signal. 2013/04/02 ed. 2013;6:pl1.

55. Shah R, Singh SJ, Eddy K, Filipp FV, Chen S. Concurrent Targeting of Glutaminolysis and Metabotropic Glutamate Receptor 1 (GRM1) Reduces Glutamate Bioavailability in GRM1+ Melanoma. Cancer Res.

American Association for Cancer Research; 2019;79:1799-809.

56. Mehnert JM, Silk AW, Lee JH, Dudek L, Jeong B-S, Li J, et al. A phase II trial of riluzole, an antagonist of metabotropic glutamate receptor 1 (GRM1) signaling, in patients with advanced melanoma. Pigment Cell Melanoma Res. 2018;31:534-40.

57. Pelletier JC, Chen S, Bian H, Shah R, Smith GR, Wrobel JE, et al. Dipeptide Prodrugs of the Glutamate Modulator Riluzole. ACS Med Chem Lett. 2018;9:752-6.

58. Shin S-S, Jeong B-S, Wall BA, Li J, Shan NL, Wen Y, et al. Participation of XCT in melanoma cell proliferation in vitro and tumorigenesis in vivo. Oncogenesis. 2018;7:86.

59. Djamgoz MBA, Onkal R. Persistent current blockers of voltage-gated sodium channels: a clinical opportunity for controlling metastatic disease. Recent Patents Anticancer Drug Discov. 2013;8:66-84. 


\section{Figure Legends}

Figure 1. Growth suppression of ER+ breast cancer cell lines by Riluzole. A, Cells seeded in 96-well plates were treated with the indicated concentrations of Riluzole (RIL, $33 \mathrm{nM}$ to $100 \mu \mathrm{M})$ or DMSO control for 7-8 days prior to staining with crystal violet. Data are presented as mean \% growth \pm standard error of the mean $($ SEM) of \% growth (vehicle $=100 \%$ ) for 5-6 technical replicates, and are representative of 2-4 independent biological assays. Dotted line box indicates data regraphed in panel B. Data were analyzed by nonlinear regression ([inhibitor] vs. normalized response), yielding the following $\mathrm{IC}_{50}[\mathrm{M}]$ estimates: SUM44, 1.27e-4; LCCTam, 2.13e-5; MM134, 2.73e-5; MCF7, 1.09e-5; LCC9, 2.23e-5; MCF10A, 4.33e-5. B, Relative response to $10 \mu \mathrm{M}$ RIL regraphed from panel A (dotted line box). Data are presented as median \% growth with upper/lower quartiles of $\%$ growth (vehicle $=100 \%$ ) for 5-6 technical replicates, and are representative of 2-4 independent biological assays. For the SUM44/LCCTam and MCF7/LCC9 cell line pairs, data was compared by Mann-Whitney test. ${ }^{* *} \mathrm{p}=0.002,{ }^{*} \mathrm{p}=0.024$.

Figure 2. Riluzole induces a histologic subtype-associated cell cycle arrest. Cells seeded in 6-well plates were treated with $10 \mu \mathrm{M}$ Riluzole or DMSO control (vehicle, Veh) for the indicated times prior to collection, fixation, staining, and cell cycle analysis. Data are presented as mean $\%$ cells \pm SD for 3-4 independent biological assays, and analyzed by two-way ANOVA followed by either Sidak's (single time point) or Dunnett's (multiple time points) multiple comparisons tests. SUM44: ${ }^{*} p=0.042,{ }^{* *} p=0.006$. LCCTam: ${ }^{*} p=0.021$. MM134: ${ }^{*} p=0.015$. BCK4: ${ }^{*} p=0.044$. MCF7: ${ }^{* * *} p<0.0001$. LCC9: ${ }^{*} p=0.013$. MCF10A: not significant.

Figure 3. Riluzole induces apoptosis and inhibits phosphorylation of pro-survival signaling molecules. A, Cells seeded in 6-well plates were treated with $10 \mu \mathrm{M}$ Riluzole or DMSO control (vehicle, Veh) for 2 days prior to staining with Annexin $\mathrm{V}$ and $\mathrm{PI}$. The percent of cells that are live $\left(\mathrm{PI}^{-}\right.$, annexin $\left.\mathrm{V}^{-}\right)$, early apoptotic $\left(\mathrm{PI}^{-}\right.$, annexin $\left.\mathrm{V}^{+}\right)$, late apoptotic $\left(\mathrm{Pl}^{+}\right.$, annexin $\left.\mathrm{V}^{+}\right)$, and necrotic $\left(\mathrm{Pl}^{+}\right.$, annexin $\left.\mathrm{V}^{-}\right)$are shown. Data are presented as mean \% cells \pm SD for 3 (SUM44) or 4 (LCCTam) independent biological assays, and analyzed by two-way ANOVA followed by Sidak's multiple comparisons test. $\mathbf{B}$, The percent of early apoptotic cells $\left(\mathrm{PI}^{-}\right.$, annexin $\left.\mathrm{V}^{+}\right)$ is regraphed from panel $A .{ }^{* * * *} p<0.0001$. C, Cells seeded in 6 -well plates were treated with $10 \mu \mathrm{M}$ Riluzole or DMSO control (vehicle, Veh) for 2 days prior to collection, lysis, and processing, then assayed using the Human Phospho-Kinase Proteome Profiler ${ }^{\mathrm{TM}}$ Array. A ratio of background-corrected intensity values for targets (phospho-kinase spots) to references (control spots) was created for each condition (DMSO and Riluzole) within each cell line. Data are presented as the geometric mean of the Riluzole:DMSO ratio for 2 technical replicates from a single experiment.

Figure 4. Riluzole in combination with Fulvestrant additively suppresses the growth of ER+ breast cancer cell lines. Cells seeded in 96-well plates were treated with $1 \mu \mathrm{M}$ Fulvestrant, $10 \mu \mathrm{M}$ Riluzole (RIL), the combination, or DMSO control (vehicle, Veh) for 7-8 days prior to staining with crystal violet. Data are presented as median with upper/lower quartiles of \% growth for 5-6 technical replicates, and are representative of 2-4 independent biological assays. Data were analyzed by Kruskal Wallis test followed by Dunn's multiple comparison test. SUM44: ${ }^{* * * *} p<0.0001$. LCCTam: ${ }^{*} p=0.027$ Veh vs. RiL, ${ }^{*} p=0.015$ Fulvestrant vs. Fulvestrant+RIL, ${ }^{* * *} p=0.0001$ Veh vs. Fulvestrant+RIL. MM134: ${ }^{*} p=0.023$ Veh vs. RiL, ${ }^{*} p=0.039$ Fulvestrant vs. Fulvestrant+RIL, ${ }^{* * *} p=0.0001$ Veh vs. Fulvestrant+RIL. BCK4: ${ }^{* * *} p=0.0006$. MCF7: ${ }^{*} p=0.021$ Veh vs. Fulvestrant, ${ }^{*} p=0.041 \mathrm{RIL}$ vs. Fulvestrant+RIL, ${ }^{* *} p=0.0001$ Veh vs. Fulvestrant+RIL. LCC9: ${ }^{* *} p=0.009$ Veh vs. RIL. MCF10A: not significant.

Figure 5. Riluzole plus Fulvestrant inhibits proliferation in primary breast tumor explant cultures. A, Pathologic data for five (5) patient-derived explants (PDEs). ER, PR, and Ki67\% are from the initial surgical specimen, and NOS = not otherwise specified. *denotes the PDE for which representative images are shown in 
panel C. B, PDEs were treated with $100 \mathrm{nM}$ Fulvestrant, $10 \mu \mathrm{M}$ Riluzole, the combination, or DMSO control (vehicle) for 2 days prior to formalin fixation, paraffin embedding, sectioning, and staining for PCNA by IHC. Data are presented as change relative to vehicle (set to 0 ) for each of the explants, and analyzed by one-sample t test vs. 0 (vehicle). ${ }^{*} p=0.013$ Vehicle vs. Combination. *denotes the PDE for which representative images are shown in panel C. C, Representative images of PCNA staining from PDE \#1055 (ILC).

Figure 6. Riluzole plus Fulvestrant inhibits $\mathrm{HCl}-013 \mathrm{El}$ tumor growth. A, Tumor latency for $\mathrm{HCl}-013$ and $\mathrm{HCl}-013 \mathrm{El}$ patient-derived xenografts (PDXs) with or without estrogen (E2) supplementation. Six (6) mice per group were orthotopically implanted with a 1-3 $\mathrm{mm}^{3} \mathrm{PDX}$ fragment, then followed until measurable tumor development (by calipers). Data are presented as percent tumor free and were analyzed by log-rank (Mantel-Cox) test. ${ }^{* * *} \mathrm{p}=0.0007$. B, Representative images of ER, PR, and Ki67 staining from $\mathrm{HCl}-013+\mathrm{E} 2$ and $\mathrm{HCl}-013 \mathrm{EI}$ tumors. C, Semi-quantitative analysis of multiplex IHC (mlHC) staining for ER, PR, and Ki67 from $\mathrm{HCl}-013+\mathrm{E} 2(\mathrm{n}=5)$ and $\mathrm{HCl}-013 \mathrm{EI}(\mathrm{n}=4)$ tumors from mice independent of those for whom tumor latency is shown in panel A. Data are presented as median with upper/lower quartiles of \% marker positivity for 5-13 fields per tumor (top row), and as overall mean \pm SD of $\%$ marker positivity (bottom row). *denotes the tumor for which representative images are shown in panel B. ^denotes tumors from the same animal. * $p=0.032$ for \%ER+. D, Forty eight (48) mice were orthotopically implanted with a 1-3 $\mathrm{mm}^{3} \mathrm{HCl}-013 \mathrm{EI}$ PDX fragment without E2 supplementation, then followed until tumors reached $\sim 100 \mathrm{~mm}^{3}$ before enrollment to one of four (4) treatment arms: control $(n=8)$, Fulvestrant $(n=9)$, Riluzole $(n=9)$, or the combination $(n=9)$. Mice were monitored for tumor growth (measured by calipers) and body weight twice per week. Data are presented as mean tumor volume \pm SEM, and were analyzed by mixed effects analysis followed by Dunnett's multiple comparisons tests at each timepoint vs. control. The baseline measurement represents tumor volume at the point of enrollment to a treatment group, and subsequent measurements are those taken while on treatment at the twice per week frequency. Bold arrow denotes the start of treatment. Purple ${ }^{*} p<0.05$ and ${ }^{* *} p<0.01$ for control vs. combination. Pink ${ }^{*} p<0.05$ and ${ }^{* *} p<0.01$ for control vs. Fulvestrant. E, Linear regression analysis was performed on volume data for each individual tumor to calculate the slope of tumor growth. Data are presented as mean slope \pm SD for all tumors shown in panel D (and Figure S5A), and were analyzed by Browne-Forsyth and Welch ANOVA followed by Dunnett's T3 multiple comparisons tests. * $p=0.023$ for Fulvestrant vs. Fulvestrant+Riluzole. 


\section{Supplementary Figure Legends}

Figure S1. Growth suppression of ER+ breast cancer cell lines by Riluzole in hormone-deprived vs. hormone-replete conditions. In these panels, data already presented in Figure 1A (hormone-replete conditions, filled symbols) were directly compared to hormone-reduced (SUM44 and LCCTam F12 cells, open symbols) or hormone-deprived conditions (MM134 CCS and MCF7 CCS cells, open symbols) as detailed in the Methods section. Cells seeded in 96-well plates were treated with the indicated concentrations of Riluzole (RIL, $33 \mathrm{nM}$ to $100 \mu \mathrm{M}$ ) or DMSO control for 7-8 days prior to staining with crystal violet. Data are presented as mean $\%$ growth \pm standard error of the mean (SEM) of \% growth (vehicle $=100 \%$ ) for $5-6$ technical replicates, and are representative of 2-4 independent biological assays. Dotted line box indicates $10 \mu \mathrm{M} \mathrm{RIL}$, the concentration used for subsequent in vitro assays. Data were analyzed by nonlinear regression ([inhibitor] vs. normalized response), yielding the following $\mathrm{IC}_{50}[\mathrm{M}]$ estimates: SUM44, 1.27e-4 hormone-replete vs. 5.5e-5 hormone-reduced; LCCTam, 2.13e-5 hormone-replete vs. 3.96e-5 hormone-reduced; MM134, 2.73e-5 hormone-replete vs. 1.16e-4 hormone-deprived; MCF7, $1.09 \mathrm{e}-5$ hormone-replete vs. $7.69 \mathrm{e}-6$ hormone-deprived.

Figure S2. Network analysis of Riluzole-inhibited protein kinase signaling. A, Metascape analysis of gene symbols corresponding to the dephosphorylated kinases and substrates in Riluzole-treated LCCTam cells shown in Figure 3C. False discovery rate (FDR) corrected $p$ values are rank-ordered in $-\log (10)$ scale. B, Graphical representation of the ratio of background-corrected intensity values for target (phospho-kinase spots) to reference (control spots) for 3 phosphorylation sites - Lyn Y397, Yes Y426, and Fak Y397 - in vehicleand Riluzole-treated SUM44 and LCCTam cells. Points represent target/reference values for 2 technical replicates, with the line connecting the geometric mean of these points.

Figure S3. Riluzole in combination with $4 \mathrm{HT}$ additively or synergistically suppresses the growth of ER+ breast cancer cell lines. Cells seeded in 96-well plates were treated with the indicated concentrations of Tamoxifen and Riluzole (RIL), alone or in every possible combination, for 7-8 days prior to staining with crystal violet. Data are presented as the mean of \% growth for 5-6 technical replicates, and are representative of 2-4 independent biological assays. Riluzole/4-hydroxytamoxifen combination experiments were analyzed using the zero interaction potency (ZIP) method [40] in synergyfinder. Surface plots for each cell line show the intensity of synergism (red) and antagonism (green), with the area of maximal interaction shown by the gray shaded box.

Figure S4. Effect of Riluzole plus Fulvestrant on Ki67 and cleaved caspase 3 in primary breast tumor explant cultures. PDEs were treated with $100 \mathrm{nM}$ Fulvestrant, $10 \mu \mathrm{M}$ Riluzole, the combination, or DMSO control (vehicle) for 2 days prior to formalin fixation, paraffin embedding, sectioning, and staining for Ki67 (A, C) or cleaved caspase 3 (B, D) by IHC. Data are presented as change relative to vehicle (set to 0 ) for each of the explants, and analyzed by one-sample t test vs. 0 (vehicle), no significant differences. In $A$ and $B$, *denotes the PDE for which representative images are shown in panels $C$ and D (\#1055, ILC).

Figure S5. Effect of Riluzole plus Fulvestrant on individual $\mathrm{HCl}-013 \mathrm{El}$ tumor growth and mouse body weight. A, Data already presented in Figure $6 \mathrm{D}$ as mean tumor volume \pm SEM are regraphed to show the growth of each individual tumor. B, Mouse weights of experimental animals for whom tumor volume measurements are shown in panel $A$ and Figure $6 \mathrm{D}$ are presented for each individual mouse. In both panels, the baseline measurement represents tumor volume $(A)$ or mouse body weight $(B)$ at the point of enrollment to a treatment group, and subsequent measurements are those taken while on treatment at the twice per week frequency. In both panels, the bold arrow denotes the start of treatment. 
Table 1: Primary Antibody/OPAL Dye Pairings and Incubation Conditions

\section{Antibody 1 Antibody 2 Antibody 3 Antibody 4 Antibody 5}

\begin{tabular}{|c|c|c|c|c|c|}
\hline Antigen & PR & Ki67 & HER2 & ER alpha & panCK \\
\hline Company & Agilent & Agilent & Agilent & Santa Cruz & Agilent \\
\hline Cat\# & M3569 & M7240 & A0485 & sc-8002 & M3515 \\
\hline Species & Mouse & Mouse & Rabbit & Mouse & Mouse \\
\hline Dilution & $1 / 50$ & $1 / 50$ & $1 / 200$ & $1 / 50$ & $1 / 300$ \\
\hline Incubation Time & $1 \mathrm{hr}$ & overnight & $1 \mathrm{hr}$ & overnight & $1 \mathrm{hr}$ \\
\hline \multicolumn{6}{|l|}{ Incubation } \\
\hline \multirow[t]{2}{*}{ Temp. } & RT & $4^{\circ} \mathrm{C}$ & $\mathrm{RT}$ & $4^{\circ} \mathrm{C}$ & $\mathrm{RT}$ \\
\hline & Breast & & Breast & Breast & Breast \\
\hline Control Tissue & Cancer & Tonsil & Cancer & Cancer & Cancer \\
\hline OPAL Fluor. & 650 & 520 & 620 & 570 & 690 \\
\hline OPAL Conc. & $1 / 140$ & $1 / 30$ & $1 / 160$ & $1 / 125$ & $1 / 30$ \\
\hline \multicolumn{6}{|l|}{ Antigen } \\
\hline Retrieval & AR6 & AR6 & AR6 & AR6 & AR6 \\
\hline
\end{tabular}


bioRxiv preprint doi: https://doi.org/10.1101/2020.07.30.227561; this version posted July 30, 2020. The copyright holder for this preprint (which was not certified by peer review) is the author/funder, who has granted bioRxiv a license to display the preprint in perpetuity. It is made available under aCC-BY 4.0 International license.

Figure 1

A.

Riluzole (RIL) Dose Response

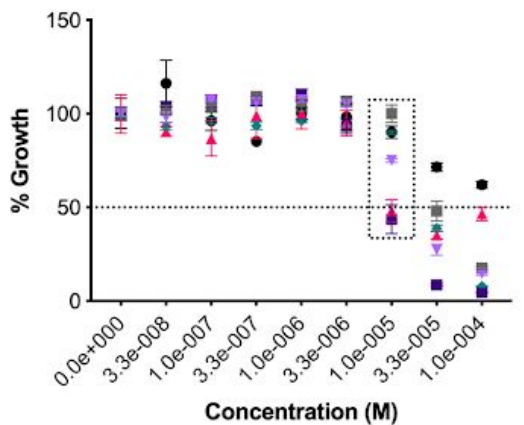

B.

- SUM44 |

4 LCCTam ILC

- MM134

- MCF7 $\mid$ IDC

- MCF10A

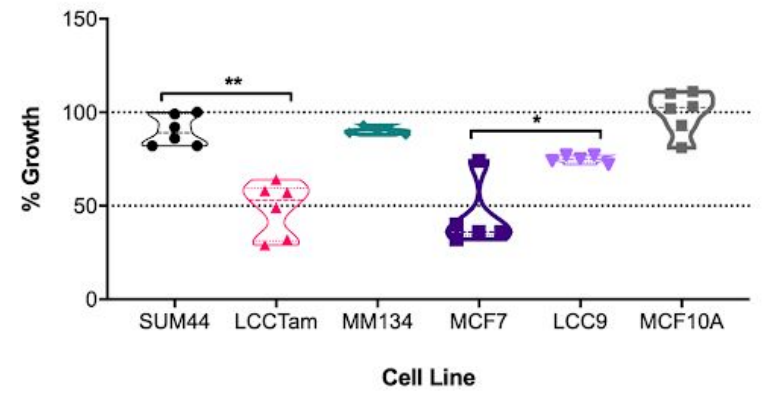


bioRxiv preprint doi: https://doi.org/10.1101/2020.07.30.227561; this version posted July 30, 2020. The copyright holder for this preprint (which

was not certified by peer review) is the author/funder, who has granted bioRxiv a license to display the preprint in perpetuity. It is made available under aCC-BY 4.0 International license.

Figure $\mathbf{S 1}$

Riluzole (RIL) Dose Response

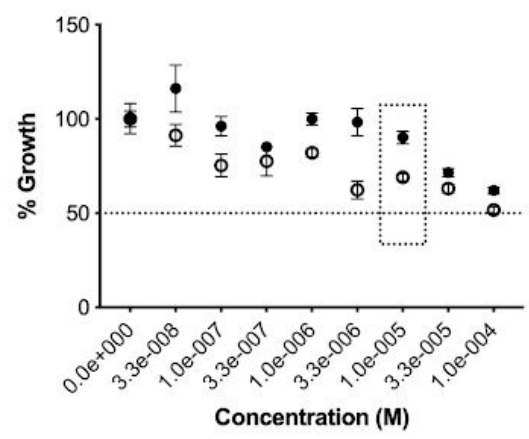

Riluzole (RIL) Dose Response

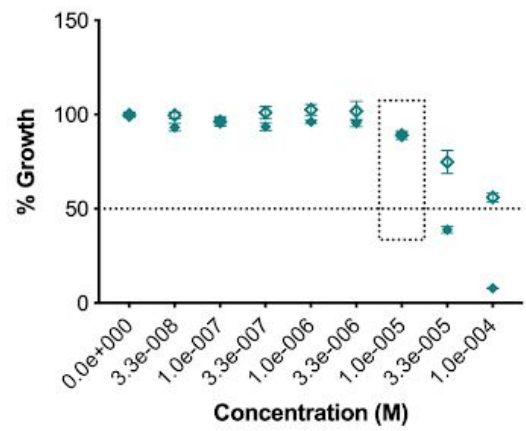

Riluzole (RIL) Dose Response

- SUM44

- Sum44F12

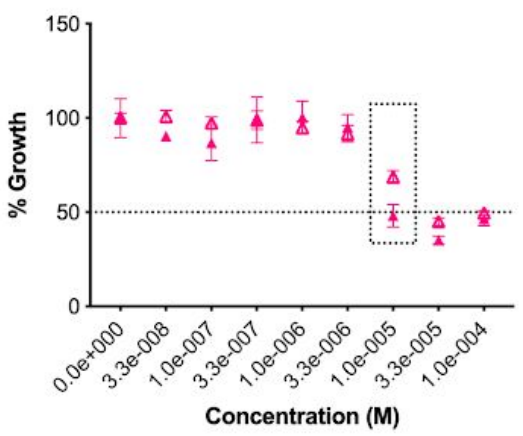

Riluzole (RIL) Dose Response

- MM134

$\diamond$ MM134 CCS

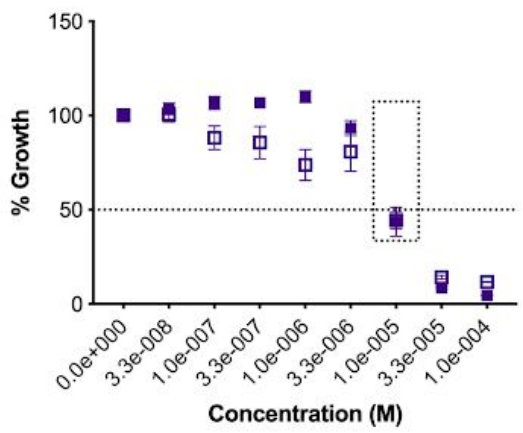

4 LCCTam

$\triangle \quad$ LCCTam F12
- MCF7

口 MCF7 CCS 
bioRxiv preprint doi: https://doi.org/10.1101/2020.07.30.227561; this version posted July 30, 2020. The copyright holder for this preprint (which was not certified by peer review) is the author/funder, who has granted bioRxiv a license to display the preprint in perpetuity. It is made available under aCC-BY 4.0 International license.

Figure 2

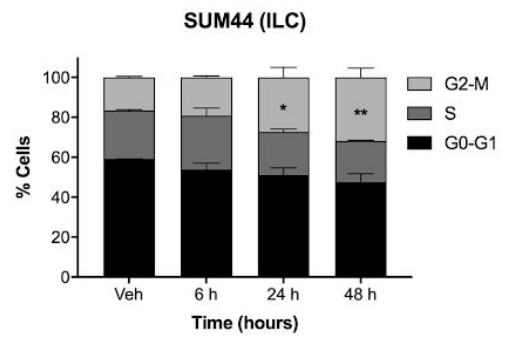

MCF7 (IDC)

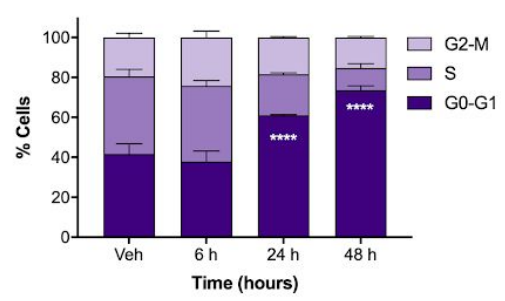

LCCTam (ILC)

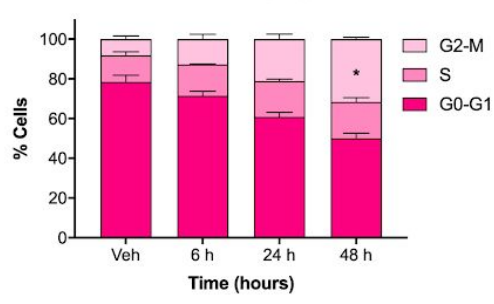

LCC9 (IDC)

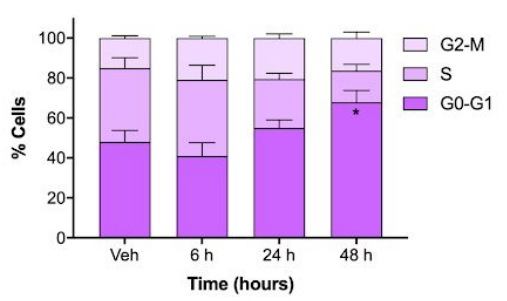

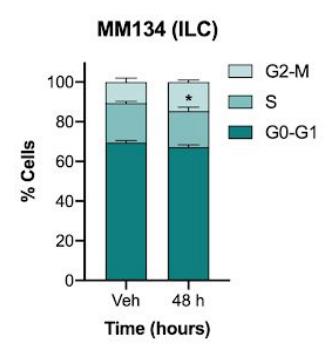

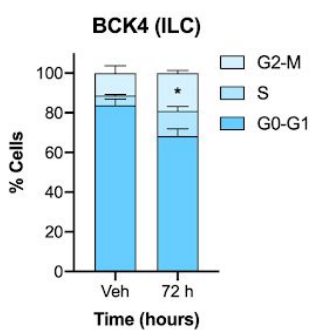

MCF10A (ER-, non-transformed breast epithelial cells)

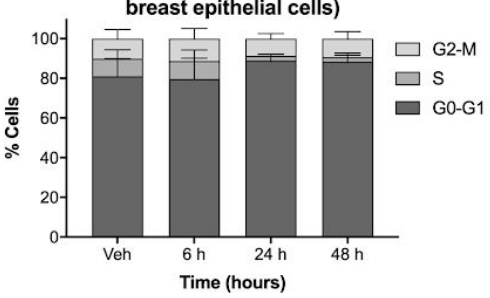


bioRxiv preprint doi: https://doi.org/10.1101/2020.07.30.227561; this version posted July 30, 2020. The copyright holder for this preprint (which was not certified by peer review) is the author/funder, who has granted bioRxiv a license to display the preprint in perpetuity. It is made available under aCC-BY 4.0 International license.

Figure 3

A.

SUM44

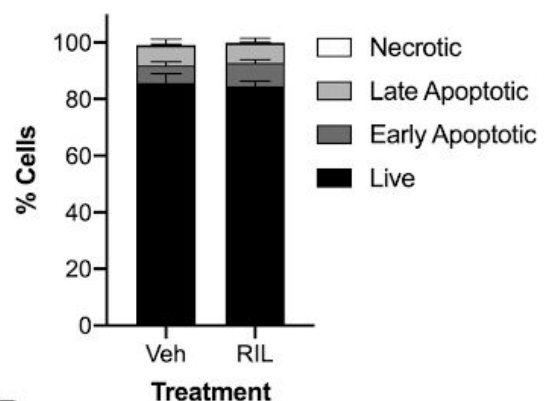

B.

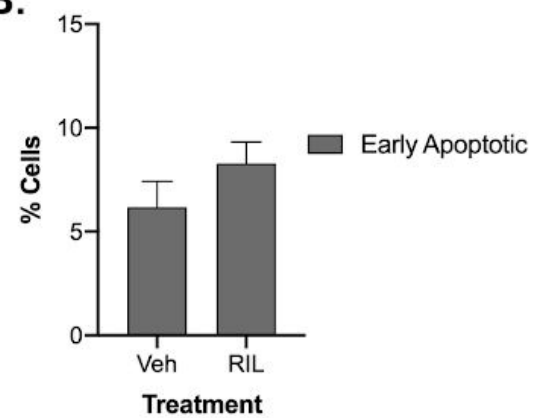

C.
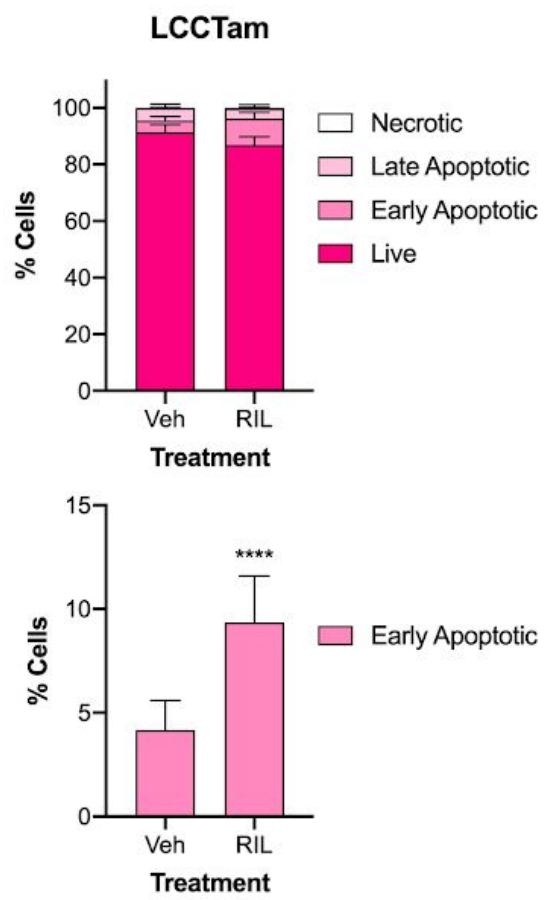

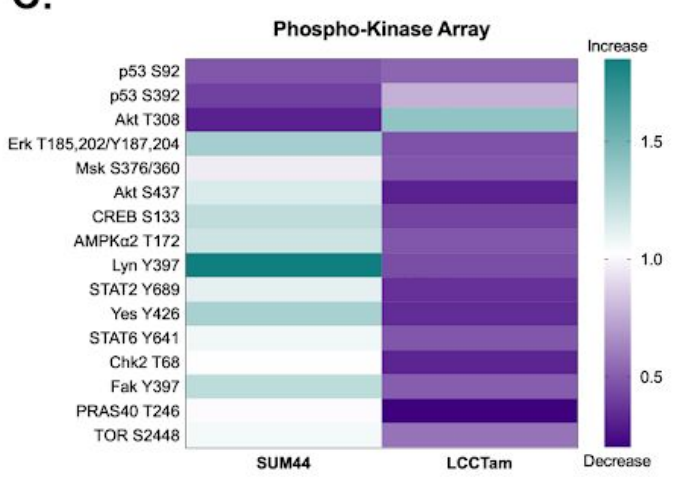


bioRxiv preprint doi: https://doi.org/10.1101/2020.07.30.227561; this version posted July 30, 2020. The copyright holder for this preprint (which was not certified by peer review) is the author/funder, who has granted bioRxiv a license to display the preprint in perpetuity. It is made available under aCC-BY 4.0 International license.

Figure S2

A.

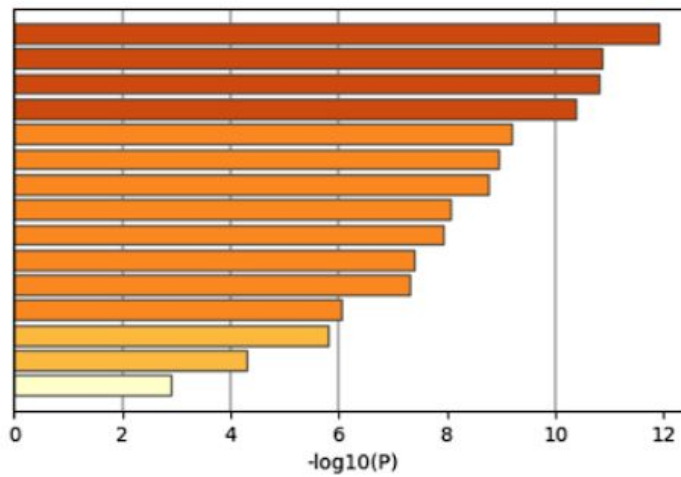

R-HSA-9006934: Signaling by Receptor Tyrosine Kinases

M124: PID CXCR4 PATHWAY

M164: PID ERBB1 DOWNSTREAM PATHWAY

R-HSA-449147: Signaling by Interleukins

M48: PID MET PATHWAY

hsa04211: Longevity regulating pathway

GO:0007169: transmembrane receptor protein tyrosine kinase signaling pathway

R-HSA-422475: Axon guidance

M87: PID LKB1 PATHWAY

R-HSA-375165: NCAM signaling for neurite out-growth

GO:0032870: cellular response to hormone stimulus

GO:0034605: cellular response to heat

hsa04630: Jak-STAT signaling pathway

GO:0035690: cellular response to drug

GO:0042176: regulation of protein catabolic process

B.

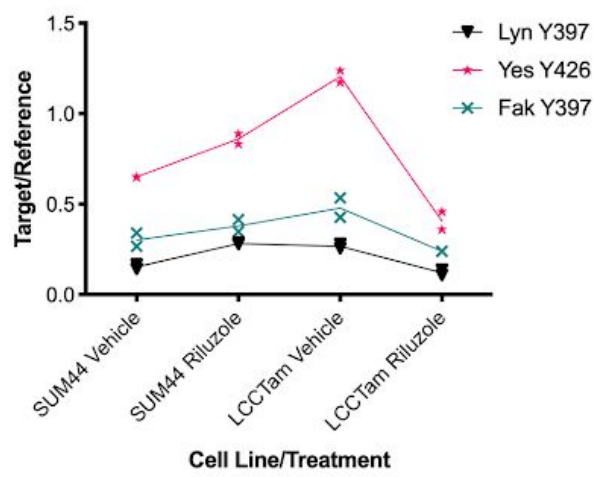


bioRxiv preprint dol: https://doi.org/10.1101/2020.07.30.227561; this version posted July 30, 2020. The copyright holder for this preprint (which was not certified by peer review) is the author/funder, who has granted bioRxiv a license to display the preprint in perpetuity. It is made

available under aCC-BY 4.0 International license.

Figure 4
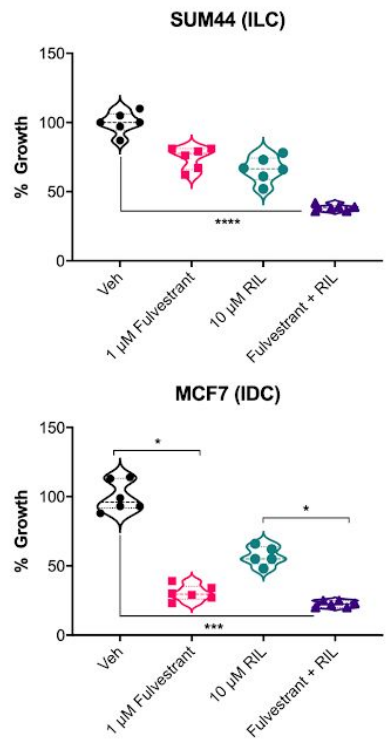
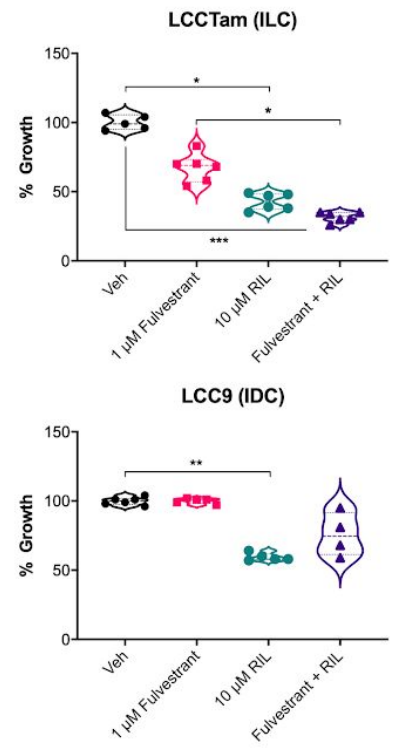

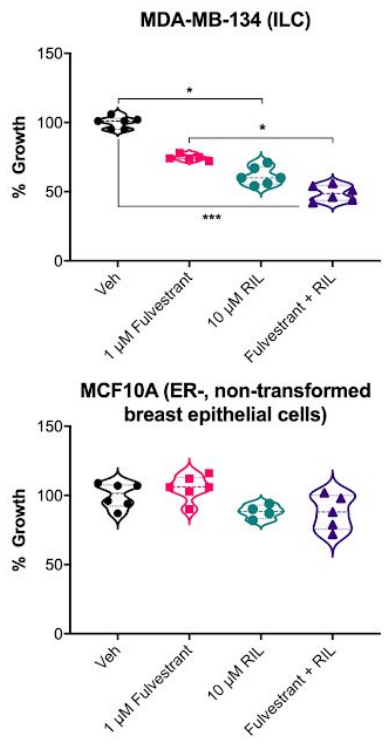


bioRxiv preprint doi: https://doi.org/10.1101/2020.07.30.227561; this version posted July 30,2020 . The copyright holder for this preprint (which was not certified by peer review) is the author/funder, who has granted bioRxiv a license to display the preprint in perpetuity. It is made available under aCC-BY 4.0 International license.

\section{SUM44 (ILC)}

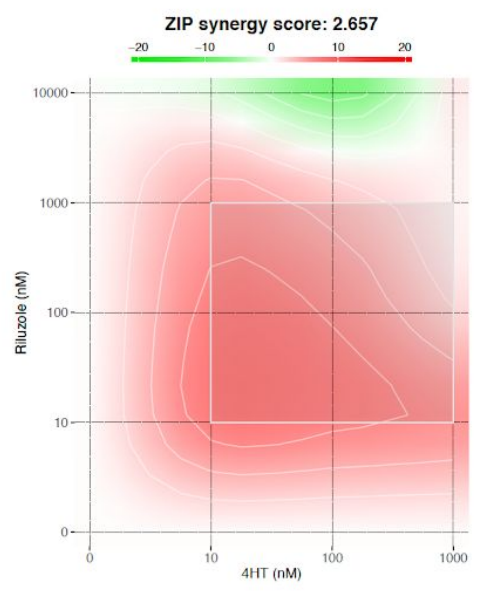

MCF7 (IDC)

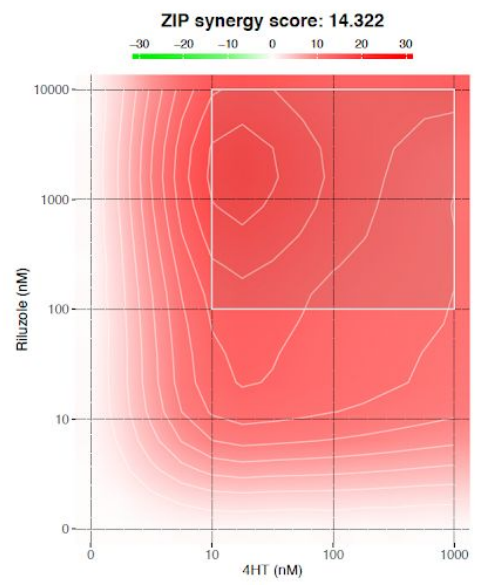

LCCTam (ILC)

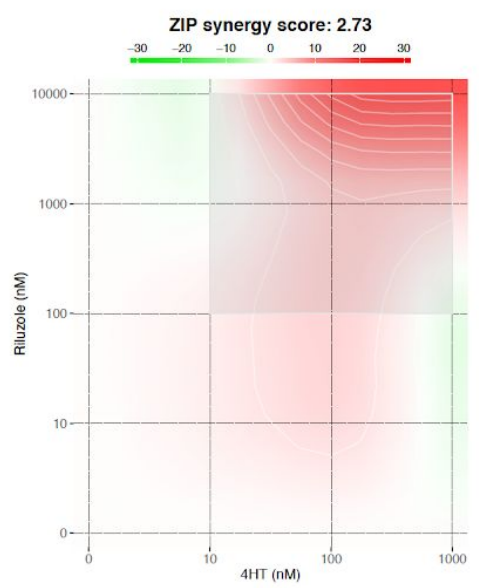

LCC9 (IDC)

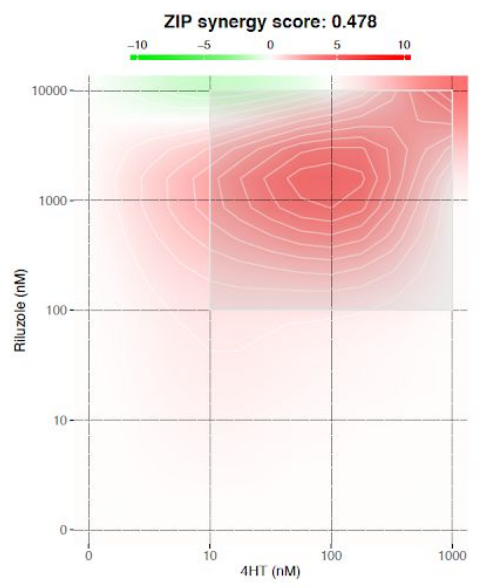

Figure S3

MCF10A (ER-, non-transformed breast epithelial cells)

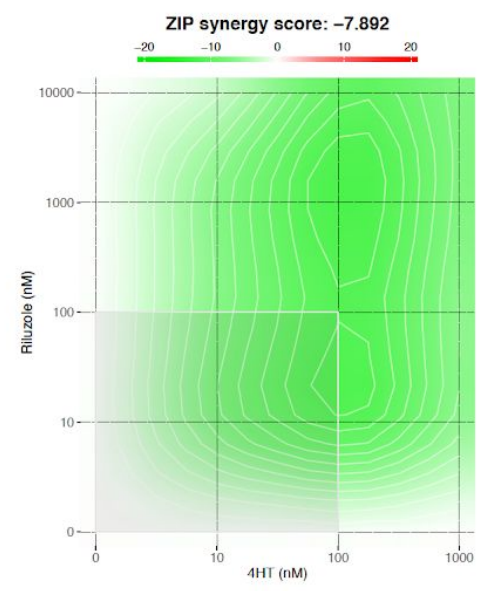


bioRxiv preprint doi: https://doi.org/10.1101/2020.07.30.227561; this version posted July 30,2020. The copyright holder for this preprint (which was not certified by peer review) is the author/funder, who has granted bioRxiv a license to display the preprint in perpetuity. It is made available under aCC-BY 4.0 International license.

Figure 5

\section{A. Patient-Derived Explants}

\begin{tabular}{|rrrlll|}
\hline \multicolumn{2}{|c|}{ Sample ID ER\% } & \multicolumn{2}{c|}{ PR\% HER2 } & \multicolumn{2}{c|}{ Ki67\% Histology Neoadjunant Chemo } \\
\hline 1044 & 95 & 95 & Negative & 50 Ductal & No \\
\hline${ }^{*} 1055$ & $90-95$ & 90 Negative & 60 Lobular & No \\
\hline 1058 & 85 & 70 Negative & 70 Ductal & No \\
\hline 1064 & 100 & 100 Negative & 35 Ductal & No \\
\hline 1099 & 100 & 100 Negative & 40 NOS & Yes \\
\hline
\end{tabular}

\section{PCNA}

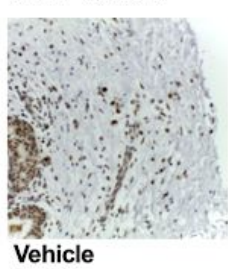

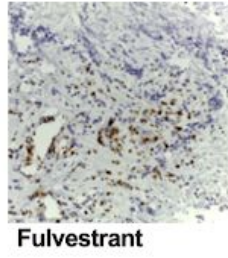
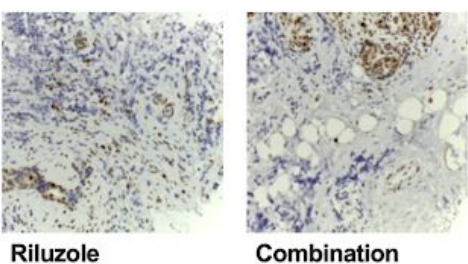

B.

PCNA

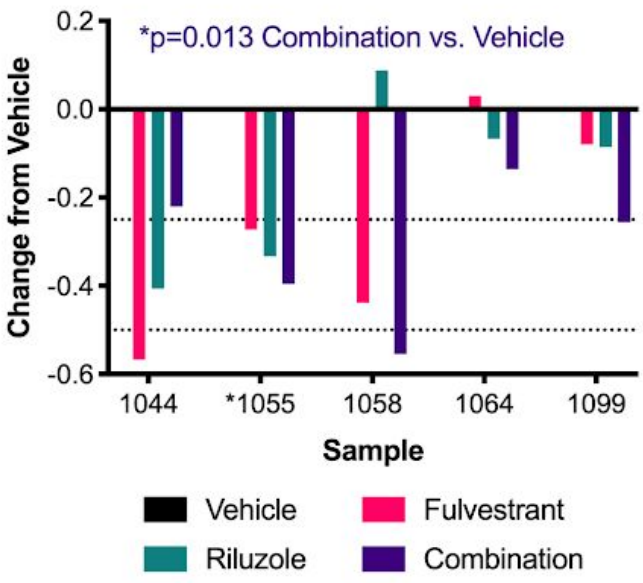




\section{Figure S4}

A.

Ki67

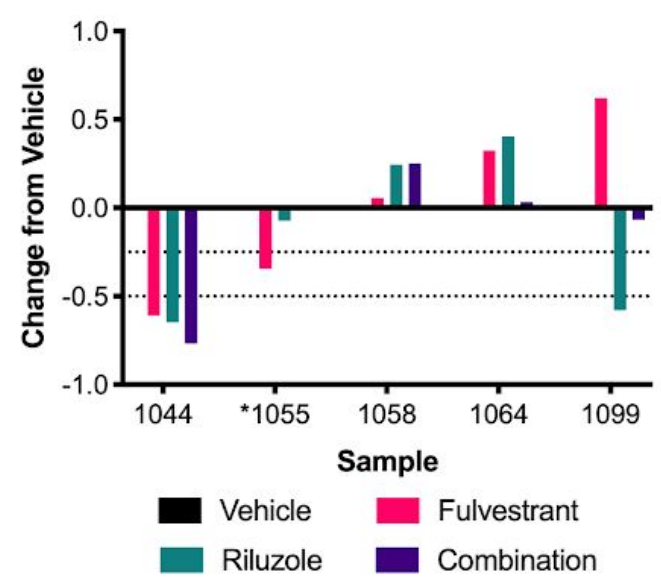

C. $\mathrm{Ki} 67$

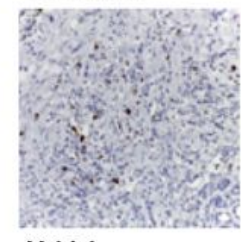

Vehicle

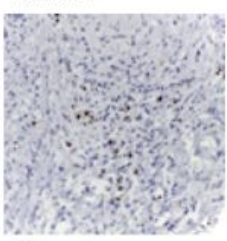

Riluzole

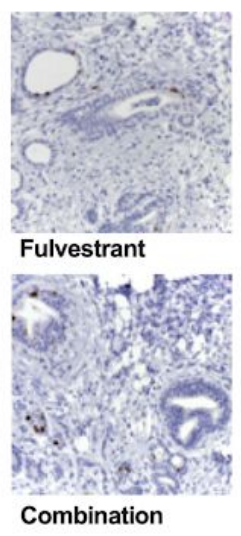

B.

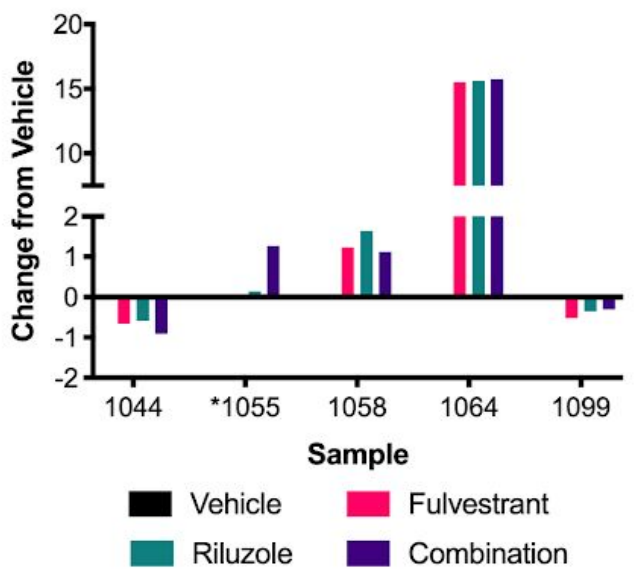

D. Cleaved Caspase 3

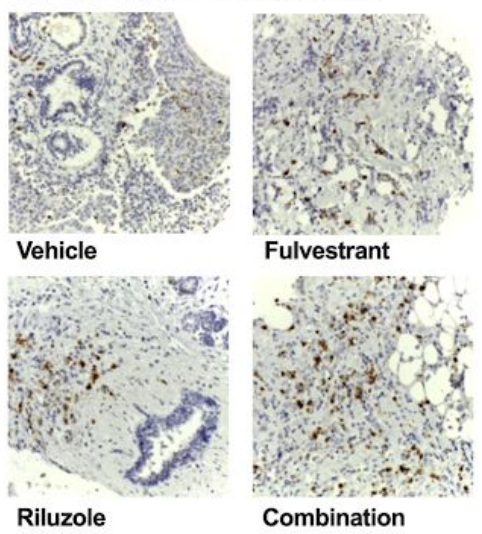


A. Time to Tumor Formation

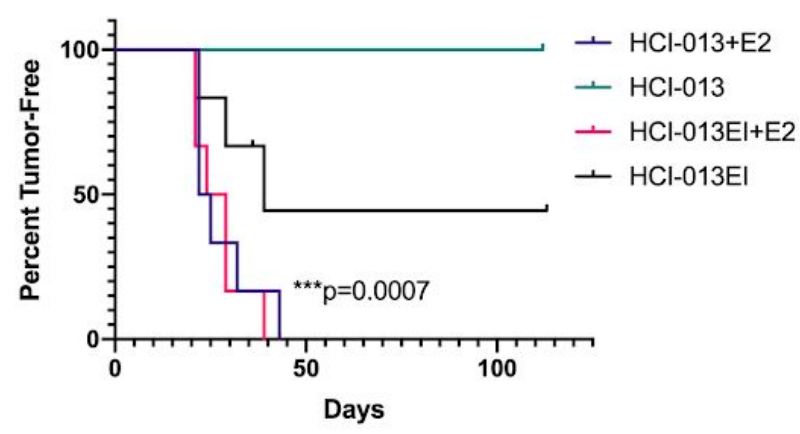

B.
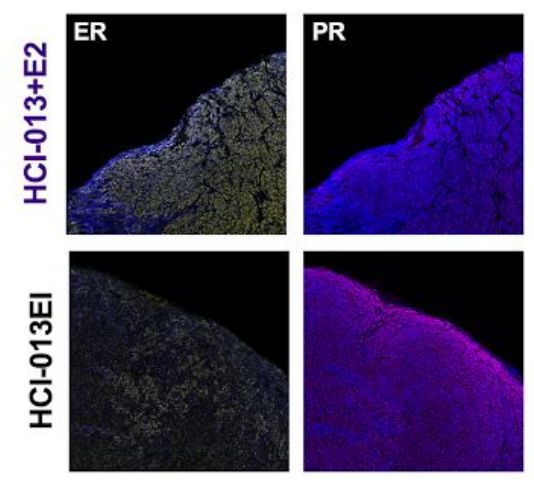

\section{Ki67}

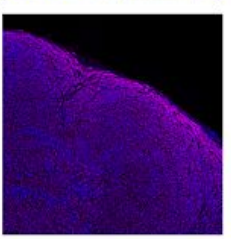

Ki67 phenotype
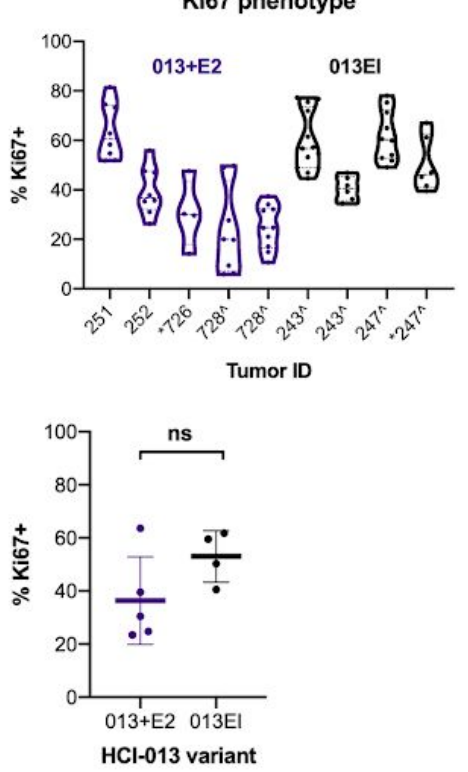

D.
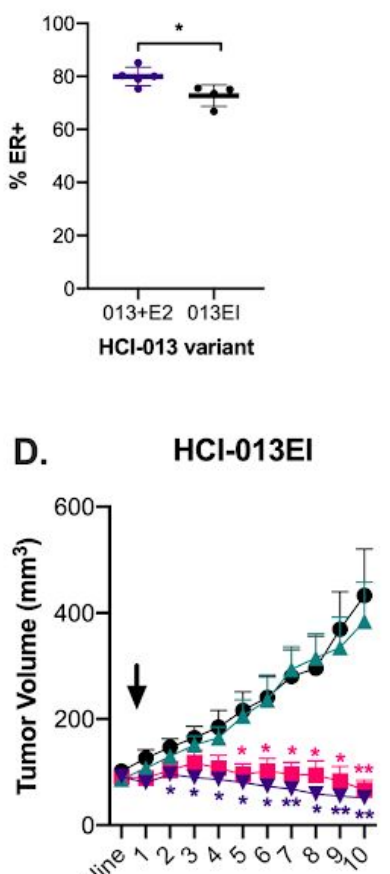

Measurement
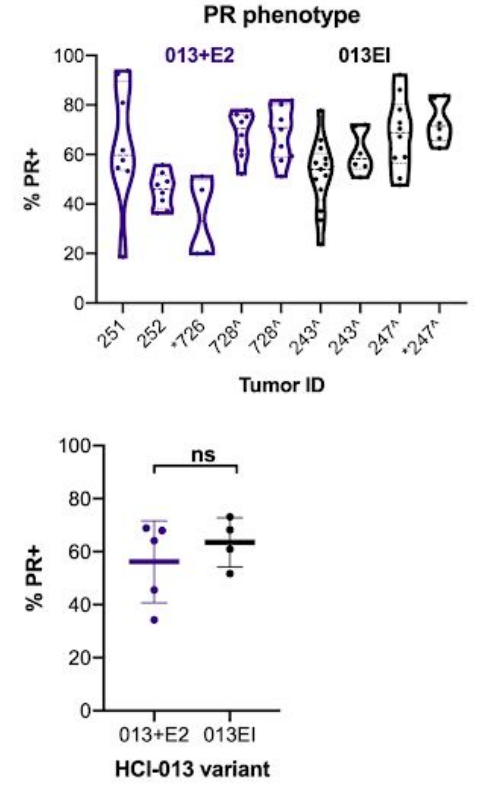

$\mathrm{HCl}-013$ variant
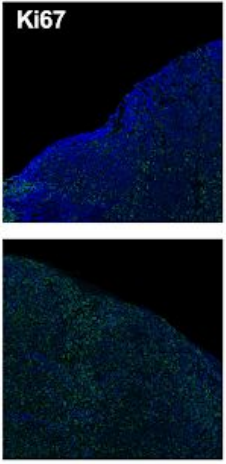

C.

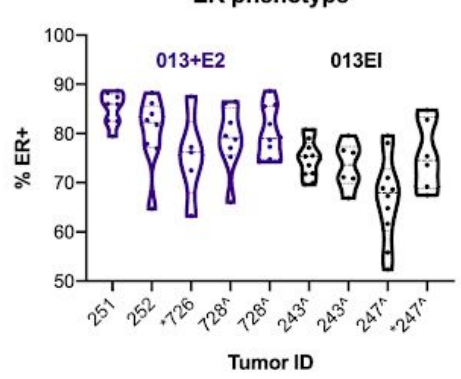

E.

HCl-013EI

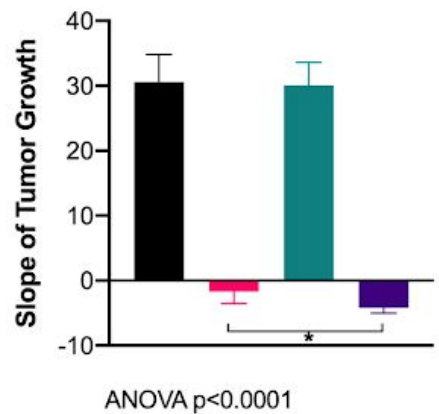

- Control - - Fulvestrant

$\downarrow$ Riluzole $\boldsymbol{\nabla}$ Fulvestrant + Riluzole 
bioRxiv preprint doi: https://doi.org/10.1101/2020.07.30.227561; this version posted July 30, 2020. The copyright holder for this preprint (which

was not certified by peer review) is the author/funder, who has granted bioRxiv a license to display the preprint in perpetuity. It is made available under aCC-BY 4.0 International license.

Figure S5

A.
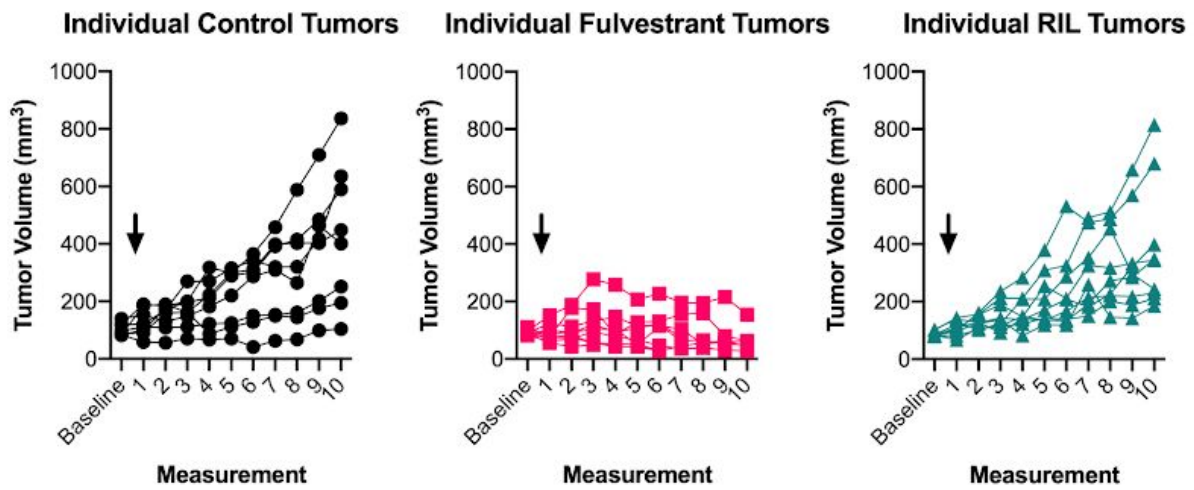

Individual RIL+Fulvestrant Tumors

B.
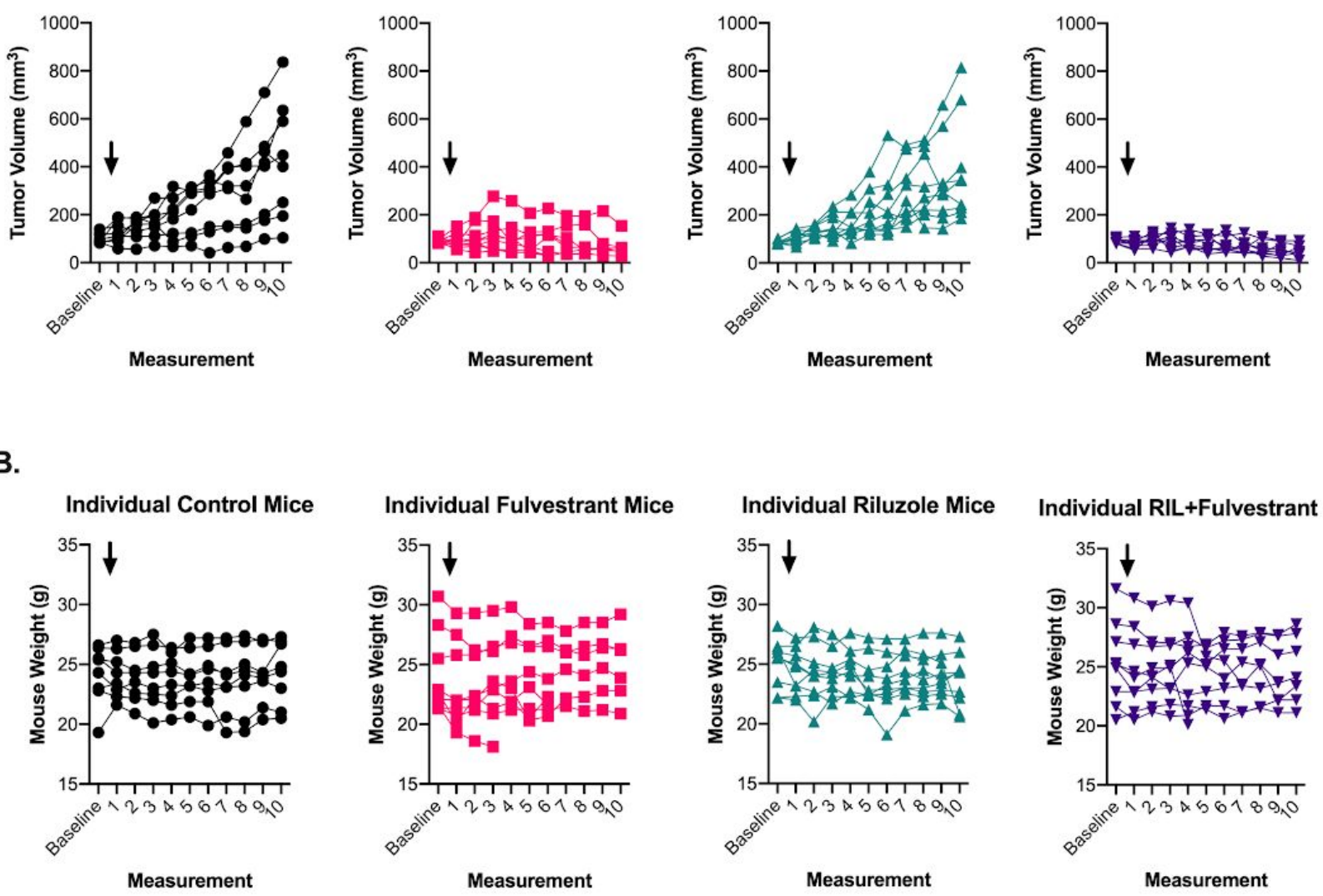

B.

Individual RIL+Fulvestrant Mice

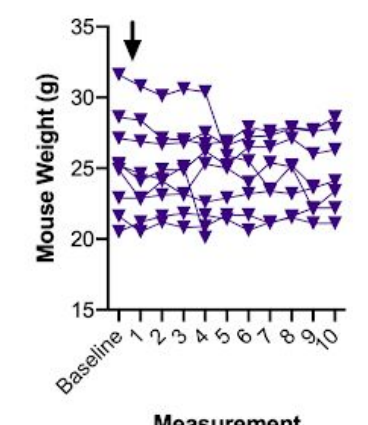

